\title{
水の需給構造に関するシステム・ダイナ之ックス論的研究 SYSTEM DYNAMICS APPROACH TO THE WATER RESOURCES SYSTEMS
}

\author{
高 棹 琢 馬* 池 淵 周 一** \\ By Takuma TAKASAO and Shuichi IKEBUCHI
}

\section{1.はしがき}

昭和 30 年以降の急激な産業・経済の発展, 人口の都 市集中, さらには生活水準の向上に伴って水需要は増大 してきており，建設省の広域利水調査報告 ${ }^{1)}$ では，昭和 60 年時点での需要量が一層増大するとしている. この ことは水資源開発を緊急に進めることを要請している が，開発拠点となるダムの適地は少なくなり，開発コス トも高くつくようになってきている．こうした事情を反 映して, 最近では水利用の合理化が検討す心゙き問題とし て叫ばれており，具体的には回収率の向上，下水処理水 の再利用, 用水原単位の引き下げ, 海水の淡水化等の方 策が考えられている.

一方，こうした水需要が増加するなかで, 必然的に排 水量は増加の一途をたどり, 河川・湖沼の公共水域の水 質污濁が進行して大きな社会問題を引き起こし，下水道 の整備の遅れと相まってその影響はますます広がってい る状況である. 従来, 公共用水域の水質污濁は污濁現象 として単独に扱われることが多かったが，この水質污濁 の問題は水資源そのものの問題であり，污染された水は もはや水資源ではないことを認識する必要があり，しか もその浄化処理には処理技術の開発コスト, 薬品投入コ ストなど, いわゆる浄化処理コストの高騰を招き，われ われの負担増となってはねかえってくる.

このようにみてくると, 水問題は需要・供給・排水污 濁が個々独立ではなく相互に関連しており，しかも量・ 質・コストの問題がこれらに階層的に関係しているとみ なければならない. 同時に, 資源の有限性の認識のもと に,これら水問題は人間活動に対しても積極的制約要因 として顕在化してきたといえる.こうした水と社会との 緊密な干渉を考えれば, 水の代謝構造を一つの社会シス

* 正会員 工博 京都大学教授 工学部土木工学教室 ** 正会員 工博 京都大学助教授 工学部土木工学教室
テムとしてとらえなければならない段階にあるといえよ 亏.

さて,こうした社会システムの階層的フィードバック 構造を分析し，そのダイナミックな特性を予測する有効 な手法にシステム・ダイナミックス（以下, SD と略す） がある.この SD はもともと経営管理に端を発したもの であり, 大規模システムのサブシステムへの分割, フィ ードバック 理論の採用, 電子計算機によるシミュレー ション技法など多くの特徴をもっているので, ローマク ラブの世界モデル2)で成功をおさめてからは社会システ ムへの適用もさかんに行われている3 . 筆者らも数年前 から水問題, 特に水需給構造とその変化過程にこの SD を適用し，いくつかの水政策情報を見出してきたし ${ }^{4), 5), ~}$ 岡田・吉川も水需給と地域活動の関連構造に SD を適用 している6).

本研究ではこれらの成果をふまえ, 産業構造の代表的 指標である工業出荷額の変化が，水とくに冷却用水不 足, 土地とくに事業所敷地面積の不足, 公共用水域の環 境悪化とくに BOD 指標等によって，それぞれ影響をう けると考え，水を中心とした SD モデルを作成するとと もに，その適用にあたっては水需給構造の条件が一段と きびしい近畿圏を選んだ.このスケールはマクロ的に水 の地域性を考え, また水利用のクローズド化をめざす上 で分析しておくべき最大限度のものと考えてよかろう. なお, 工業出荷額には水因子以外の影響が大きく作用す ることはもちろんであるが，本研究では水に関連した作 用を重点的に把握するという立場からモデル展開をはか る. この場合, 従来とられてきたような工業出荷額を工 業成長率などで外生化し予測する手法では, 水資源の有 限性, 水環境の悪化などで今日では適切を欠くと考えら れるので，その内生化によるモデル化を行って，その分 析・予測・評価への接近を主目的とした.

以下, 本研究の内容を要約すると, 2. では SD の適 用にあたってリアルシステムの観察・構造理解が重要で 
あるので，まず社会システムとしての水需給構造を概観 し，モデル作成の手助けとする．3．ではモデル作成の 手法となる SD についてその概要を述べ，4. では以上 の知識を十分にふまえて, 水需給構造をいくつかのサブ システムに分割し、フィードバック・ループを考慮しな がら, 具体的に SD モデルを構成する. 最後に, 5. で はいくつかの政策変数を組み合わせて各レベルのダイナ ミックな特性をシミュレートし, 得られた結果を考察す るとともに, 将来の水政策に対する提言を訊みる.

\section{2. 社会システムとしてみた水需給構造}

戦後の農業から重化学工業中心主義へ移っていった産 業構造の変化は, 大都市への人口および施設の集中をも たらし, 都市構造の変化を引き起こした．そして都市は 水の大量消費型に変質し, 上水や工業用水の使用量が増 加し, それが大量の都市排水を生み，水質污濁を引き起 こすこととなった.これら上水や工業用水の使用量増加 は, 地下水規制・水源開発の遅れ・開発コストの高騰な どと相まって, 水不足といら量的問題を, また大量の都 市排水は下水道整備の遅れ・排出規制の不明確さに助長 され，水質污濁という質的問題を顕在化させている. し かも公共用水域の水質污濁は水源機能を低下させ, 浄化 処理 コストを高騰させるとともに，水不足の 遠因にも なっている.

こうした事実は, もはや水問題は需要・供給・排水污 濁を個々独立にとらえることはできず，それらの有機的 な関連構造を量・質・コストの 3 側面を包含した形で総 合的にとらえなければならないことを意味している.さ
らに，われわれ人間生活・産業活動にとって現況の水需 給は量・質・コストの面で決して満足のいくものではな く,そのギャップを改善・緩和させるために講じた対策 手段があるものは遅れを伴って, あるものはひずみを もって再びわれわれの生活・産業構造にはねかえってい き, 時間の経過とともにこのプロセスが繰り返されてい るとみなければならない.

このように考えると,われわれは水需給構造を一つの 社会システムとして体系的にとらえるべきであり，しか もそれらシステムの階層的フィードバック構造を正しく 認識しなければならないことに気づくであろら．図一1 はこうした考えのもとで需要・供給・排水污濁の相互関 倸をフローチャートで示したものである. もちろん, 水 は人間生活のみならず自然の構成要因として重要な役割 を担っているので，人間生活中心の考え方は水にとって 危険側といわねばならないし，また社会・経済・技術の 変容に水環境は鋭敏に反応し, それにより変化した環境 が人間の生活や産業活動に影響を与えるといらことも注 意しておかなければならない。このことを図中では環境 基準という要素で概念的に考慮することにしている.

以上述べたことから明らかなように，水需給システム の広汎でかつ複雑な相互関係およびそれらのダイナミッ クな特性はもはや従来の解析的手法では取り扱いらる範 囲を越えており, シミュレーション手法の導入が不可欠 となってくる.ここに, システムの階層的フィードバッ ク構造を組み入れたシミュレーション手法, すなわち $\mathrm{SD}$ の水需給構造への適用が考えられる.

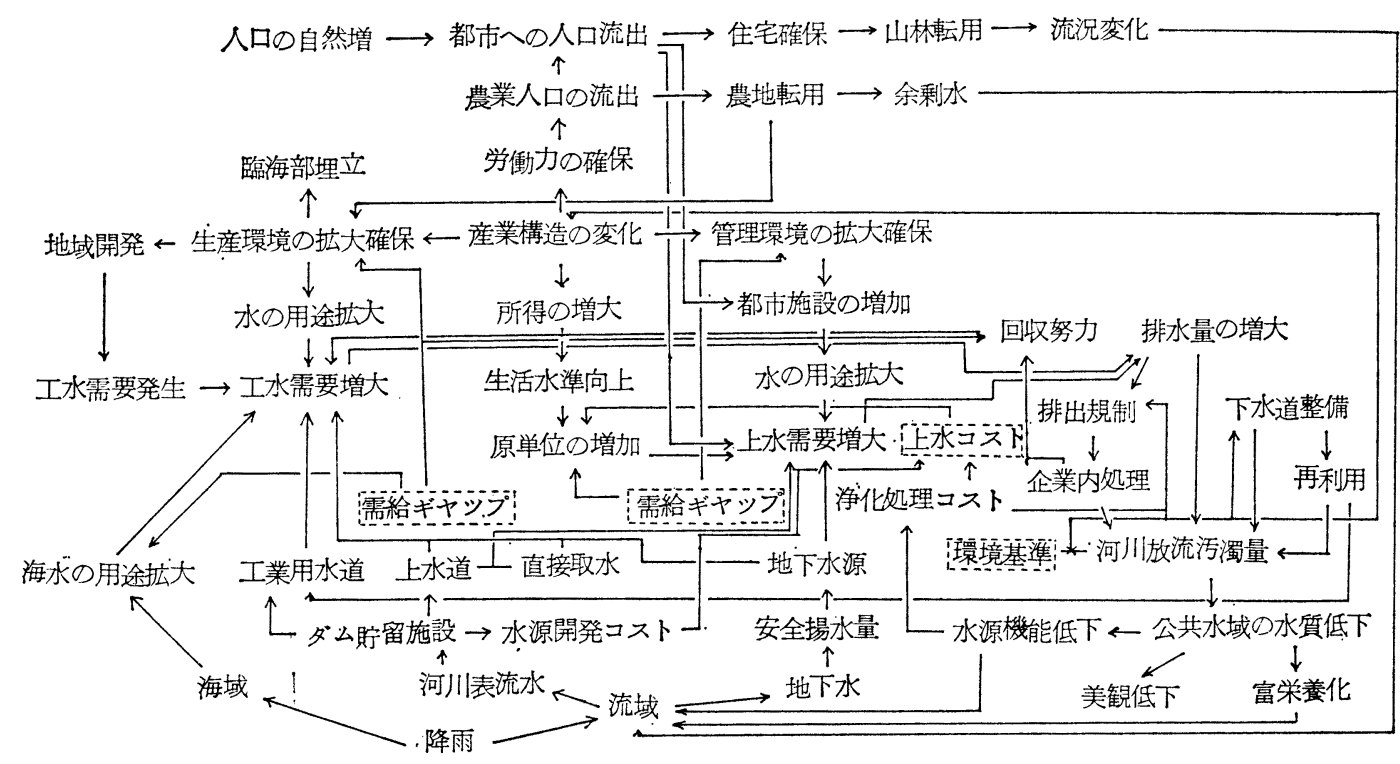

図一1 水墨給構造のトータルフロー 
3. システム・ダイナミックス (SD) と その基本概念

\section{（1） SD とその特徵}

J.W. Forrester 教授によって創始されたインダスト リアル・ダイナミックズは, その後, 企業・都市・世 界などのダイナミックなメカニズムを解明する総称とし てシステム・ダイナミックスとよばれるようになった。

$\mathrm{SD}$ は 1) 物, 生物のみならず人間活動をも含んだ現 象をシステムとして把握し，そのシステムにはインフォ メーション・フィードバック・ループが存在するとみな してシステム工学的なアプローチによってトータルシス テムをいくつかのサブシステムに分解する，2）サブシ ステム間に作用する因子・要素の因果関係を解明してシ ステム方程式をたて, 総合して数学モデルを作り, 電子 計算機によってシミュレートする，3）モデルの実証を 経たのち,さまざまな条件下でテストし，意志・政策変 数のメカニズムの解明に努める, という特徴を有する.

したがって，SD によれば, システム分析・モデル構 成の過程でシステムの構造について理解を深め, シミュ レーションによってダイナミックな挙動が定量的に把握 できる. しかもインフォメーション・フィードバック・ ループはフィードバックされた情報を目的值に対比し て，偏差のあった場合にその偏差をなくすようにシステ ムの挙動をコントロールするメカニズムを内蔵するた め, SD はそのコントロールのメカニズムの解明と理解 にも役立つ ${ }^{8}$. これらがとりもなおさず, 従来の方法に ない利点であり，SD が目的とするところでもある.

\section{（2） SD モデルの基本的な構造}

$\mathrm{SD}$ モデルは基本的には図一2 に示すような制御され たフローによって相互に連結された蓄積の場（レベル） が交互に現われる構造をもつ. 寸なわち, 次に述べる4 つのファクターから成り立っている.

i ）レベル（ $\square$ で表わす）

ii）あるレベルの中味 (内容) を他のレベルへ運ぶフ ロー（一ーで表わす）

iii）レベル間のフロ 一の大きさ (レイト) を決める意志決定機構

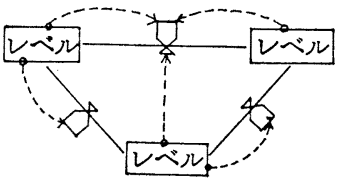

(匚יなで表わす)

iv）意志決定機構々 レベルを結ぶ情報の通 路 (……で表わす)

これらによって一見
複雑に思える現象も SD によってモデル化が可能とな る.

\section{（3）計算の方式（システム方程式）}

連続的な時間の流れは, 同一の長さの短い時間間隔 DT に分けられ，時間とともに変化するレイトは DTの 間は一定であることを仮定する.

方程式は時間の流れ J, K, L にしたがって, 解答時間 $\mathrm{DT}$ ごとに計算される. レベル方程式は $\mathrm{J}$ 時点のレベ ルと時間間隔 $\mathrm{JK}$ のレイトから $\mathrm{K}$ 時点のレベルを計算 するプロセスを示す．たとえば，

$$
\text { L.K }=\mathrm{L} . \mathrm{J}+(\mathrm{DT}) \text { (RI.JK }- \text { RO.JK) }
$$

のような形で表現できる.ここに, L.K : K 時点でのレ ベル, L.J : J 時点でのレベル, RI.JK : JK のインプッ トレイト, RO.JK : JK のアウトプットレイト,である.

こうして $\mathrm{K}$ 時点のレベルが計算された後で次のステッ プである時間間隔 KL のレイトが決められ, このレイ トが次の時間のシステムのフローをコントロールするこ とになる. 以後も同様のプロセスで時間が DT ずつ進 むことによって次々とレイトとレベルが決定されていく (図一3).

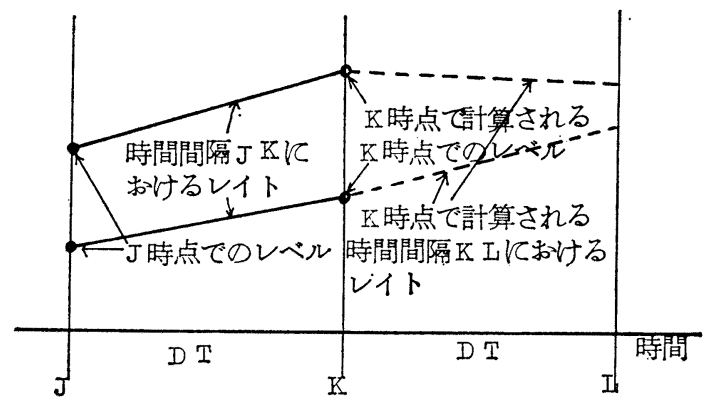

図一3 SD の計算方式

次にレイト方程式であるが，これは意志決定機構に よって決定されたフローのレイトを数式化したもので, 一般的な形で表現できないが，K時点で計算され，次の 時間間隔 KL 間のフローのレイトを決定するものであ る.

\section{4. 水需給構造のシステム・ダイナミックス・ モデル}

\section{（1） システム分析の目的とサブシステムへの分割}

人間生活・産業活動にとって水が不可欠である以上， その向上・発展のためには水需要の増加は必須である. だが, 水需給の現況から理解されるように, 一方では有 限な資源量, 水質污濁の悪化, 諸コストの高騰, などの 制約をうけて近い将来, 水需給が破たんする危惧も予想 
される. すなわち, 現在, 将来にわたる水需要の増加, それに伴う水質污濁が必須と考えられる状況では，水の 需給構造は上記のような制約のなかで決定されていくも のと考えられる.

そこで本研究のシステム分析の目的としては必要な工 業生産の拡大を可能にし, 人閒生活を営むのに十分なだ けの水資源を確保しながら, しかも廃水の排出先である 河川の環境基準を守っていくためには，どのような手段 を用いて，いかなる政策ルールによって実施していけば よいのかを, システムの動向をみながら, その量的な目 安を見い出すことにある.このことは, 水そのものの量 的な動きが質, コストなどからのはねかえりをうけて, どのように動くかといったことを追求することによって 水政策の上で重要となる指標を求めることでもある.な お, 河川の污濁といった複雑な現象をすべて包含するこ とは不可能であるので, ここでは一過性の有機質污濁物 質を代表的に取り上げ，その BOD 濃度のみを水質対象 としており, 蓄積性の污濁物質, たとえば重金属や放射 性物質などは考慮の対象外としている.

次にトータルなシステムをサブシステムに分割し, サ ブシステム内の構造ならびにサブシステム間の因果関係 を明らかにしなければならない. 本研究では図一1のト 一タルフローを考えて, 次の 6 つのサブシステムに分割 して，モデルの内部構造をより詳細にさぐることにし
た・すなわち、

i）人口構造のサブシステム, ii) 土地構造のサブシス テム，iii）上水需給構造のサブシステム，iv）工水需給 構造のサブシステム，v）水源開発構造のサブシステム， vi）排水污濁処理構造のサブシステム

以下では，水需給構造の条件が一段ときびしくなって いる近畿圏 (滋賀・京都・大阪 - 兵庫・奈良・和歌山の 2 府 4 県）を適用対象に，これらサブシステムを構成す るシステム方程式を展開し，上記のシステム分析をはか る.なお，以下の記号についてはレベルには末尾に L を，レイトには $\mathrm{R}$ を付してある。

\section{（2）人口構造のサブシステム}

このサブシステムでは人口の自然増加はもとより，産 業活動に伴う 1 次, $2 \cdot 3$ 次産業就業者人口および他地 域からの流入就業者人口の増減を考えている.表一1 は これらを具体的にシステム方程式で一括表示したもので ある。

\section{（3）土地構造のサブシステム}

この部分では，1 次産業就業人口の減少に伴い手離さ れた耕地が事業所敷地および宅地一転換されるプロセ ス，臨海埋立地が事業所敷地に付加されるプロセスを取 り扱っている. 表一2 はこの部分のシステム方程式を示

表一1 人口構造サブシステムのシステム方程式

\begin{tabular}{|c|c|c|c|c|}
\hline & レベル名 & レヘル方程式およびレイト方程式 & 記 号 の 説 明 & 倩 \\
\hline 人 & 総 $\underset{\mathrm{PL}}{ }$ & $\begin{aligned} \text { PL.K }= & \text { PL.J }+ \text { DT } * \text { PR.JK } \\
\text { PR.JK }= & \text { PL.J*C } 19: \text { PL.J } /(P I L . J \\
& + \text { PAL.J) } \leq \text { C } 31 \\
\text { PR.JK }= & \text { C } 31 *(P I L . J+P A L . J) * P W R . J ~ \\
& \text { PL.J } /(\text { PIL.J }+ \text { PAL.J) }>\text { C } 31\end{aligned}$ & 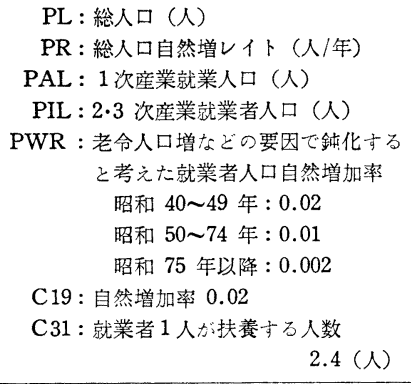 & 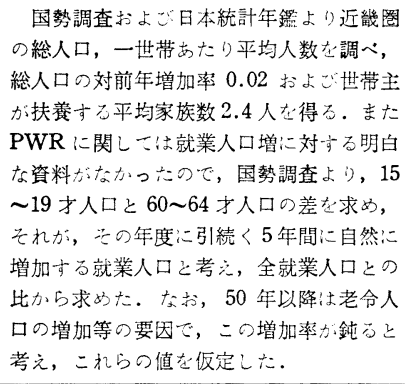 \\
\hline ブ & $\begin{array}{c}1 \text { 次産業 } \\
\text { 就業者人口 } \\
\text { PAL }\end{array}$ & $\begin{array}{l}\text { PAL.K }=\text { PAL.J }+ \text { DT } *(P A R . J K \\
\quad-\text { PAIR.JK) } \\
\text { PAR.JK }=\text { PAL.J*PWR.J } \\
\text { PAIR.JK }=\text { PAL.J*C } 23: \\
\quad \text { WIL.K/WIL.J } \geq C 37 \\
\text { PAIR.JK }=0: \text { WIL.K } / \text { WIL.J }<C 37\end{array}$ & $\begin{aligned} & \text { PAR : } 1 \text { 次産業就業人口自然增加レイト } \\
& \text { (人/年) }\end{aligned}$ & 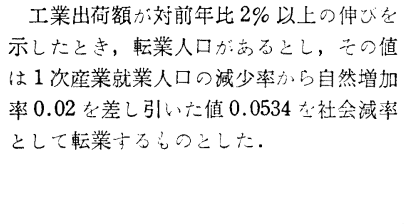 \\
\hline 厶 & $\begin{array}{c}2 \cdot 3 \text { 次剷業 } \\
\text { 就業者人口 } \\
\text { PIL }\end{array}$ & $\begin{aligned} & \text { PIL.K }= \text { PIL.J +DT } *(P I R . J K \\
&+ \text { PAIR.JK +PIOR.JK }) \\
& \text { PIR.JK }= \text { PIL.J*PWR.JK } \\
& \text { PIOR.JK }=\text { PIL.J*max }(B 9-A 9 * J, 0)\end{aligned}$ & $\begin{aligned} \text { PIL : } 2 \cdot 3 \text { 次産業就業者人口（人） } \\
\text { PIR : } 2 \cdot 3 \text { 次産業就業者人口自然増加レ } \\
\text { イト（人/年） } \\
\text { PIOR : 流入人ロレイト（人/年） } \\
\text { B9: } 0.0160 \\
\text { A9: } 0.0023\end{aligned}$ & 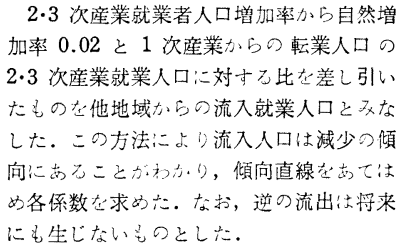 \\
\hline
\end{tabular}

改善の方向 : シミュレーンョン結果と 50 年実績值との比較では総人口および就業者人口の自然增加率のさらなる鈍化を考㦄した方がよい。 
表一2 土地構造サブシステムのシステム方程式

\begin{tabular}{|c|c|c|c|c|}
\hline & レベル名 & レヘル方程式およびレイト方程式 & 記 号 の 説 明 & 備 \\
\hline & $\begin{array}{l}\text { 耕地面 積 } \\
\text { AAL }\end{array}$ & $\begin{array}{l}\text { AAL.K }=\text { AAL.J-DT } * \text { ACAR.JK } \\
\text { ACAR.JK }=(\text { PAL.I }- \text { PAL.J }) * C 4\end{array}$ & $\begin{array}{l}\mathrm{AAL}: \text { 耕地面積 (ha) } \\
\mathrm{ACAR}: \text { 耕地面積減少レイト（ha/年） } \\
\mathrm{C} 4: 0.1375(\mathrm{ha} / \text { 人) }\end{array}$ & $\begin{array}{l}1 \text { 次産業就業人口と耕地面積との間に直 } \\
\text { 線的相関があるてて } 1 \text { 次産業就業人口の } \\
\text { 変化数に一定の比 } 0.1375 \mathrm{ha} / \text { 人を乗じるこ } \\
\text { とで与えた.これは転換可能面積としてス } \\
\text { トックされていく. }\end{array}$ \\
\hline & $\begin{array}{c}\text { 転 換可能 } \\
\text { 耕地面積 } \\
\text { ACAL }\end{array}$ & 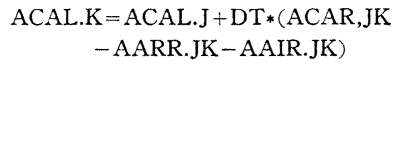 & $\begin{array}{l}\text { ACAL : 転換可能耕地面積 (ha) } \\
\text { AARR : 耕地から宅地への転換レイト } \\
\text { (ha/年) } \\
\text { AAIR : 耕地から 事業所敷地への転換レ } \\
\text { イト (ha/年) }\end{array}$ & \\
\hline $\begin{array}{l} \pm \\
\text { 地 } \\
\text { 構 }\end{array}$ & $\begin{array}{c}\text { 宅地面栍 } \\
\text { ARL }\end{array}$ & $\begin{aligned} \text { ARL.K } & =\text { ARL.J+DT*AARR.JK } \\
\text { AARR.JK } & =\min (\text { PIL.J*A } 1-B 1 \\
& - \text { ARL.J,ACAL.J*ARL.J } / \\
& \cdot(\text { AIL.J + ARL.J)) }\end{aligned}$ & $\begin{array}{l}\text { ARL : 宅地面積 (ha) } \\
\text { A1 }: 0.0178 \text { (ha/人) } \\
\text { B1 }: 34400 \text { (ha) }\end{array}$ & 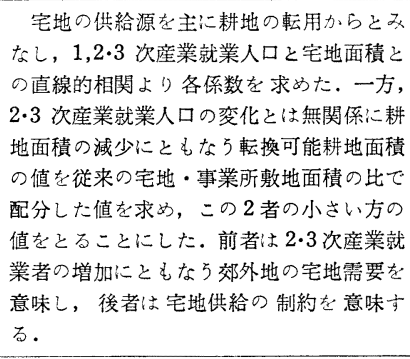 \\
\hline $\begin{array}{l}\text { 造 } \\
\text { サ } \\
\text { フ } \\
\text { ン } \\
\text { ス }\end{array}$ & $\begin{array}{l}\text { 理立可能 } \\
\text { 面 } \\
\text { ASL 積 }\end{array}$ & $\begin{array}{l}\text { ASL.K }=\text { ASL.J }-\mathrm{DT} * \text { ASIR.JK } \\
\text { ASIRX.JK }=\min (\text { ASL.J, (WIL.J } \\
\quad * \text { WAI.J }- \text { AIL.J }) *(1-\mathrm{C} 3)) \\
\text { ASIR.JK }=\max (\text { ASIRX.JK,O })\end{array}$ & $\begin{array}{l}\text { ASL : 埋立可能面積 (ha) } \\
\text { ASIRX : 補助変数 } \\
\text { ASIR : 事業所用埋立レイト (ha/年) } \\
\text { WAI : 工業出荷額むたりの事業所敷地面 } \\
\text { 皘 (ha/百万円) } \\
\text { C3 : } 0.66\end{array}$ & 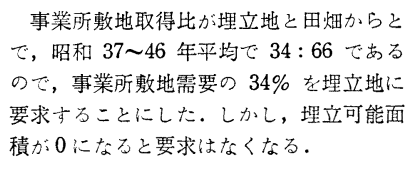 \\
\hline $\begin{array}{l}\text { テ } \\
厶\end{array}$ & $\begin{array}{l}\text { 事業所敷地 } \\
\text { 面 } \\
\text { AIL 積 }\end{array}$ & $\begin{aligned} \text { AIL.K }= & \text { AIL.J }+\mathrm{DT} *(\text { AAIR.JK } \\
& + \text { ASIR.JK) } \\
\text { AAIR.JK }= & \min ((\text { WIL.J*WAI.J } \\
& - \text { AIL.J)*C } 3, \text { ACAL.J*AIL.J } / \\
& (\text { AIL.J }+ \text { ARL.J) }) \\
\text { WAI.K } & =\text { WAIIJ } * C 2: \text { 昭和 } 45 \text { 年以前 } \\
\text { WAI.K } & =\text { WAI.J*C } 24: 45 \text { 年以降 }\end{aligned}$ & $\begin{array}{l}\text { AIL : 事業所敷地面積 (ha) } \\
\text { AAIR : 耕地から事業所敷地への転換レイ } \\
\quad \text { ト (ha/年) } \\
\text { C2 }: 0.918 \\
\text { C } 24: 0.99\end{array}$ & 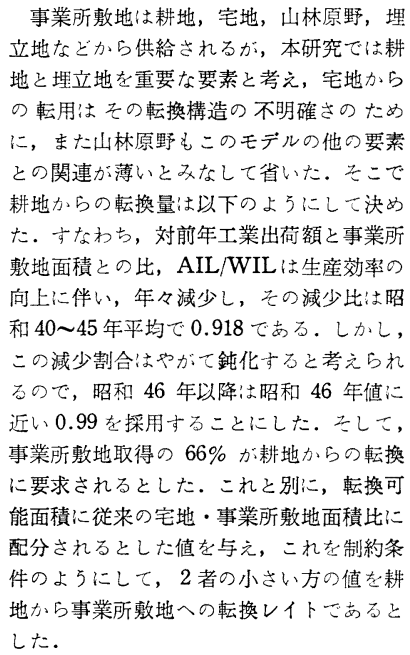 \\
\hline
\end{tabular}

改善の方向：ンミュレーンョン結果と実績值との比較では, 耕地面積減少レイトがも5少し大きいよ5である。事業所敷地には宅地, 山林原野からの

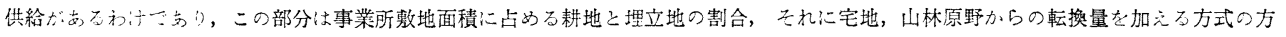
方実際的て古万5。

したものである。

\section{（4）上水需給構造のサブシステム}

この部分では, 上水需要を家庭用と業務用に分け, 前 者においては人口, 生活水準, 上水道普及率に, 後者は 工業出荷額に関連させて予測している. さらに昭和 50 年以降は水源開発や浄化処理などに伴う上水コストの上 昇が需要を抑制する構造をも導入している. 一方, 上水
供給はダムなどの建設により開発供給される河川表流水 と, 従来からの地下水供給でまかなっている. 表一3 は この部分のシステム方程式である.

\section{（5）工水需給構造のサブシステム}

この部分では, 工水を冷却・温調用水とその他工水 （原料，ボイラー，洗浄・処理用水）に分け，それぞれ の需要を工業出荷額に結びつけた弾性值予測法 ${ }^{10)}$ で与え 
表一3 上水需給構造のシステム方程式

\begin{tabular}{|c|c|c|c|c|}
\hline & レヘル名 & レヘル方程式およびレイト方程式 & 記 号 ○説 明 & 備 \\
\hline サ & $\begin{array}{c}\text { 家庭用上水 } \\
\text { 需 要 量 } \\
\text { HW }\end{array}$ & 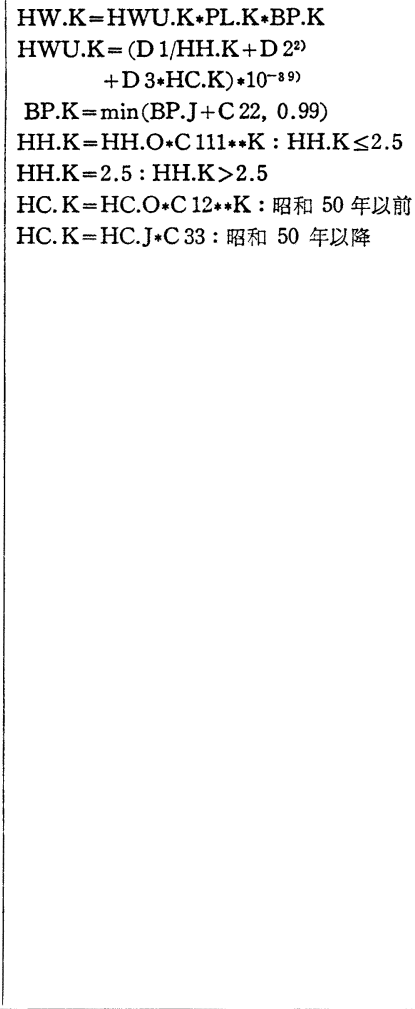 & 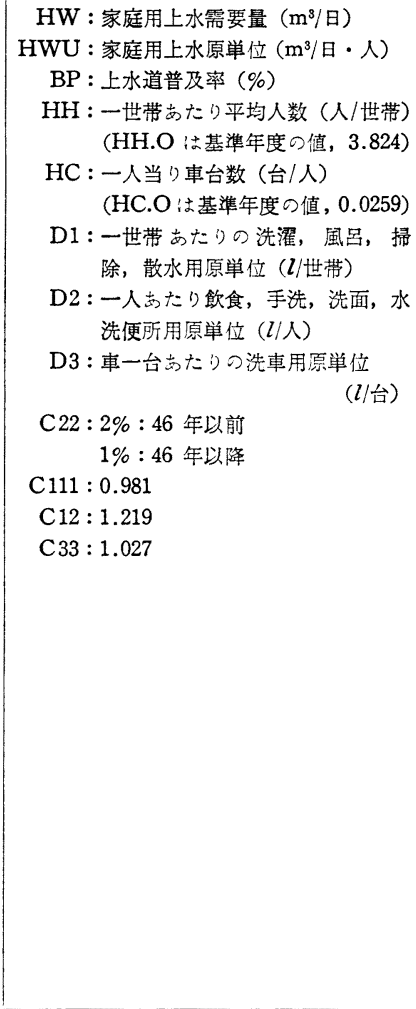 & 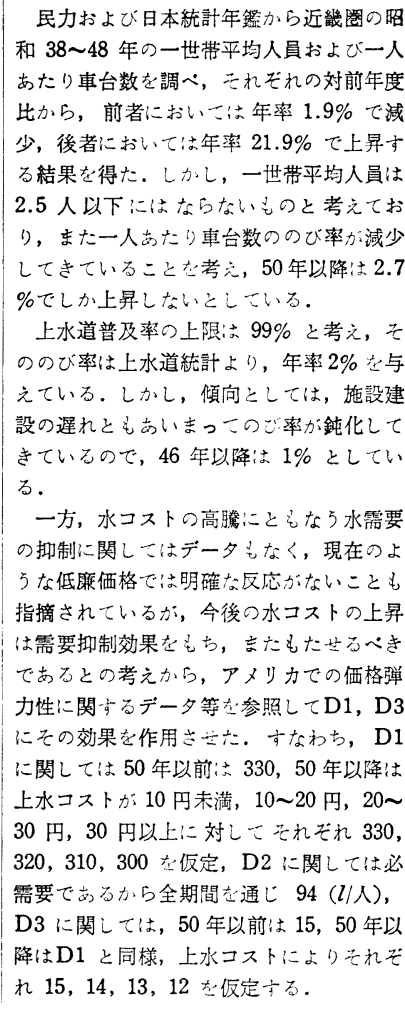 \\
\hline 7 & $\begin{array}{c}\text { 業務用上水 } \\
\text { 需 要 量 } \\
\text { HNW }\end{array}$ & $\begin{array}{l}\text { HNW.K }=(\text { HS.K } * H U . K+B 5) * D \\
\text { HS.K }=\text { A } 8 * \text { WIL.K }+ \text { B } 8 \\
\text { HU.K }=\text { HU.J*C } 26\end{array}$ & 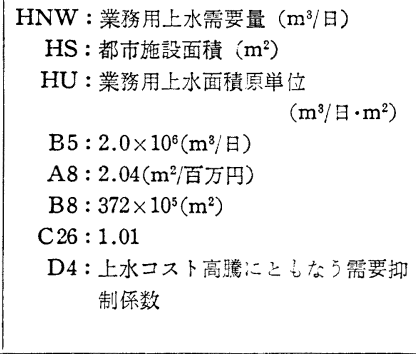 & 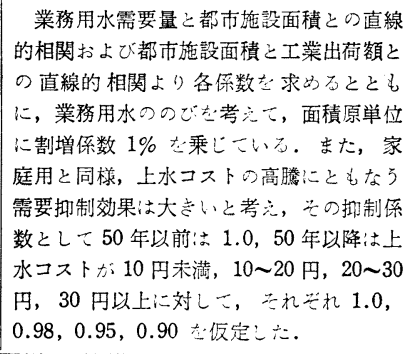 \\
\hline & $\begin{array}{l}\text { 総上水需要 } \\
\text { 量 HWD } \\
\text { と充足率 } \\
\quad \text { BSD }\end{array}$ & \begin{tabular}{|c} 
HWD.K $=$ HN.K + HNW.K \\
BSD.K $=$ BWW.K $/$ HWD.K \\
HNS.K $=1.0$, HSS.K $=1.0:$ \\
$\quad$ BSD.K $\geq 1.0$ \\
HNS.K $=$ BSD.K, HSS.K=1.0: \\
$\quad 0.9 \leq$ BSD.K $<1.0$ \\
HNS.K $=0.9$, HSS.K $=\max (0.1$ \\
$\quad+$ BSD.K, C 36$):$ BSD.K $<0.9$ \\
HNWW.K $=$ HNW.K + HNS.K \\
HWW.K $=$ HW.K $* H S S . K$ \\
HWD $1 . K=$ HNWW.K + HWW.K
\end{tabular} & 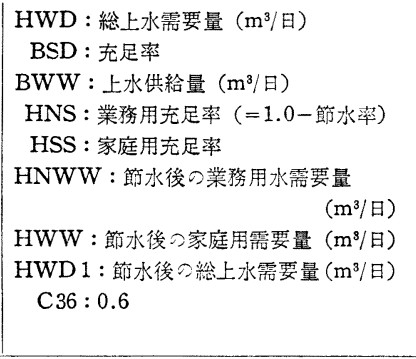 & 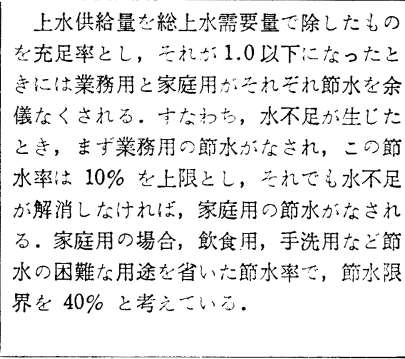 \\
\hline & $\begin{array}{c}\text { 上水供給量 } \\
\text { BWW }\end{array}$ & $\mathrm{BWW} \cdot \mathrm{K}=\mathrm{BW} \cdot \mathrm{K} *(1.0-\mathrm{C} 150)+\mathrm{C} 200$ & $\begin{array}{l}\mathrm{BWW}: \text { 上水供給量 }\left(\mathrm{m}^{3} / \text { 日 }\right) \\
\mathrm{BW}: \text { 浮水場受水量 }\left(\mathrm{m}^{3} / \text { 日 }\right) \\
\mathrm{C} 150: \text { 瀮水率 } \\
\mathrm{C} 200: \text { 地下水依存量 }\end{array}$ & 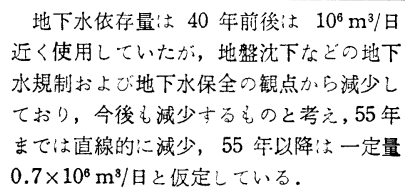 \\
\hline
\end{tabular}

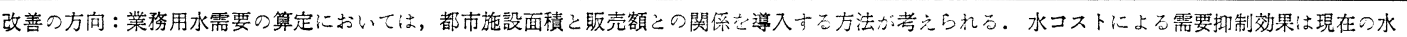
コスト程度ではないかるしれないか，将来的には，岕るいは概念的には点るものと考元られる。具体的なデー夕はないので,これらの仮 定值の罗当性については検討できないか，今後, こうした方面の研究成果だ得られれ莯導入していきたい。 
表一4 工水需給構造のシステム方程式

\begin{tabular}{|c|c|c|c|c|}
\hline & レベル名 & レヘル方程式およびレイト方程式 & 記 号 の 説 明 & 满 \\
\hline & $\begin{array}{c}\text { 椧却・温調 } \\
\text { 用水需要量 } \\
\text { WCD }\end{array}$ & $\begin{aligned} & \text { WCD.K }=\text { WCD.O } \\
& *(\text { WIL.K/WIL.O }) * * C 7 \\
& \text { RCWU.K }=\text { WCD.K/WIL.K }: \\
& \text { WC.K } \leq 10^{6} \\
& \text { RCWU.K }=\text { WCD.K/WIL.K*0.9: } \\
& \text { WC.K }>10^{6}\end{aligned}$ & 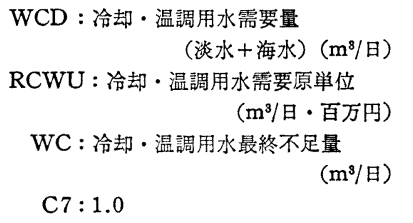 & $\begin{array}{l}\text { 参考文献 10)より“用水量の比は出荷額 } \\
\text { の比の } \alpha \text { 乗である”とされているので, } \\
\text { 工業統計表 (用地・用水編) データより } \\
\alpha=1.0 \text { を得, これを C } 7 \text { とした.なお, } \\
\text { WCD.O および WIL.O は基準年度の值 } \\
\text { を意味する. }\end{array}$ \\
\hline & $\begin{array}{c}\text { その他工水 } \\
\text { 需 要 量 } \\
\text { WID }\end{array}$ & $\begin{array}{l}\text { WID.K }=\text { WID.O } \\
\qquad *(\text { WIL.K/WIL.O }) * * C 8 \\
\text { RIWU.K }=\text { WID.K/WIL.K }\end{array}$ & $\begin{array}{l}\text { WID : その他工水需要量（淡水） } \\
\text { RIWU : その他工水需要原単位 } \\
\text { C8 } \quad\left(\mathrm{m}^{3} / \text { 日 }\right) \\
\left(\mathrm{m}^{3} / \text { 日・百万円 }\right)\end{array}$ & $\begin{array}{l}\text { 上式と同様に工業統計表データより } \alpha= \\
0.3 \text { を求め, これを } \mathrm{C} 8 \text { とした. 海水の工 } \\
\text { 水への用途としては椧却用が } 46 \text { 年度て } 97 \\
\% \text { 以を占めているので, 冾却用のみを考 } \\
\text { 虑した. }\end{array}$ \\
\hline & $\begin{array}{l}\text { 上水道から } \\
\text { の工水供給 } \\
\text { 量 } \\
\quad \text { BWS }\end{array}$ & $\begin{aligned} \text { BWS.K } & =\max (B W S X . K, O) \\
\text { BWSX.K }=\min (B W W . K & \\
& * \text { BIP.K, BWW.K-HWD.K) } \\
\text { BIP.K }= & \text { BIP.J*C } 32\end{aligned}$ & $\begin{array}{l}\text { BWS : 上水道からの工水供給量 }\left(\mathrm{m}^{3} / \text { 日 }\right) \\
\text { BWSX : 補助変数 } \\
\text { BIP : 上水道供給量に占める工業用供給 } \\
\text { 量の割合 } \\
\text { C32: } 0.97\end{array}$ & $\begin{array}{l}\text { 上水道供給総量に占める工業用の割合は } \\
\text { わずかではあるが, 減っている, また, 上 } \\
\text { 水の供給先である家庭用, 業務用の需要量 } \\
\text { に対して供給量に余裕がある場合にのみ工 } \\
\text { 業への供給があると考え, 実績値との比較 } \\
\text { によって, その小さい方を上水道からの工 } \\
\text { 水供給量と考えた. }\end{array}$ \\
\hline 水 & $\begin{array}{l}\text { その他水源 } \\
\text { からの工水 } \\
\text { 供給量 } \\
\quad \text { WIE }\end{array}$ & $\begin{aligned} \text { WIE.K } & =\text { WIE. } O *(1.0-0.025 * \mathrm{~K}): \\
& \text { WIE. } \mathrm{K} \geq 0.7 * \text { WIE. } \mathrm{I} \\
\text { WIE.K } & =0.7 * \text { WIE. } \mathrm{:} \\
& \text { WIE. } \mathrm{K}<0.7 * \text { WIE. } \mathrm{O}\end{aligned}$ & $\begin{aligned} \text { WIE : } & \text { その他水源（地表水・伏流水・地 } \\
& \text { 下水からの直接取水分）からの工 } \\
& \text { 水供給量 }\left(\mathrm{m}^{3} / \text { 日) }\right.\end{aligned}$ & $\begin{array}{l}\text { その他水源からの工水供給量は年々わず } \\
\text { かであるが減っこいる.しかし，工水需要 } \\
\text { においては将来ともこ5した水源からの直 } \\
\text { 接取水には依存すると考えられ, 基準年度 } \\
\text { の } 70 \% \text { を確保水量とした. }\end{array}$ \\
\hline 需 & $\begin{array}{c}\text { 工業用水道 } \\
\text { 供 給 量 } \\
\text { WI }\end{array}$ & $\begin{aligned} \text { WI. K }= & 3.249 * 10^{6} /\left(1+2.4136 \mathrm{e}^{-0.8379 *}\right) K: \\
& \text { WA.K }>\text { WI.K }+ \text { BW 10.K } \\
\text { WI.K }= & \max (\text { WA.K }- \text { BW 10.K,O }): \\
& \text { WA.K } \leq \text { WI.K }+ \text { BW 10.K }\end{aligned}$ & $\begin{array}{r}\text { WI : 工業用水道供給量 }\left(\mathrm{m}^{3} / \text { 日) }\right. \\
\text { WA : 河川表流水開発量 }\left(\mathrm{m}^{3} / \text { 日) }\right. \\
\text { BW } 10: \text { 上水道取水量 }\left(\mathrm{m}^{3} / \text { 日 }\right)\end{array}$ & $\begin{array}{l}\text { 工業用水道供給量は順調にのびており, } \\
\text { 今後とも望まれるが, 地方自治体, 企業に } \\
\text { とってはての財政負担・コスト增などに } \\
\text { よって必ずしも満足しているわけではな } \\
\text { いここでは, 河川表流水の開発量が十分 } \\
\text { ある場合には, 工業用水道供給量に関する } \\
\text { 既往データから求めたロジステイック曲線 } \\
\text { 值で, そ5でない場合は開発量から上水道 } \\
\text { 取水量を差し引いた分だけしか供給されな } \\
\text { いと考えた. }\end{array}$ \\
\hline$\pi$ & $\begin{array}{l}\text { 工業用水全 } \\
\text { 淡水供給量 } \\
\text { WIS } \\
\text { 亡椧却・温 } \\
\text { 調用淡水一 } \\
\text { 次供給量 } \\
\text { WCFS }\end{array}$ & $\begin{array}{l}\text { WIS.K }=\text { WI.K + BWS.K + WIE.K } \\
\text { WCFS.K }=\max (\text { WIS.K - WID.K.O) }\end{array}$ & $\begin{array}{r}\text { WIS : 工業用全淡水供給量 }\left(\mathrm{m}^{8} / \text { 日) }\right. \\
\text { WCFS : 冾却・温調用淡水一次供給量 } \\
\left(\mathrm{m}^{8 / 8}\right)\end{array}$ & $\begin{array}{l}\text { 冷却用は海水・回収水など直接の淡水源 } \\
\text { のみに頼らなくこさよいか，その他工水は } \\
\text { 淡水源に依存しており, とにかく淡水源て } \\
\text { その他工水需要を満たし, 残りを冾却用に } \\
\text { 供給し, 冷却用不足分は海水と回収水で補 } \\
\text { と考える. }\end{array}$ \\
\hline & $\begin{array}{l}\text { 椧却・温調 } \\
\text { 用海水供給 } \\
\text { 量 } \\
\text { SWSL }\end{array}$ & $\begin{array}{l}\text { SWSL.K =SWSL.J+DT } * \text { SWSR.JK } \\
\text { SWSR.JK = A } 2 * \text { WIL.J+B2-SWSL.J }\end{array}$ & $\begin{array}{l}\text { SWSL : 冾却・温調用海水供給量 }\left(\mathrm{m}^{8} / \text { 日) }\right. \\
\text { SWSR : 冷却用海水供給量増加レイト } \\
\text { ( } \\
\text { A2 }: 0.26\left(\mathrm{~m}^{3} / \text { 日 }\right) \\
\text { B2 }: 1.76 \times 10^{6}\left(\mathrm{~m}^{3} / \text { 日) }\right.\end{array}$ & $\begin{array}{l}\text { 冾却用海水の利用量は出荷額との間に直 } \\
\text { 線的関係があるので, 最小二乗法で係数を } \\
\text { 決定した. }\end{array}$ \\
\hline & $\begin{array}{c}\text { 回収水量 } \\
\text { RWSL }\end{array}$ & 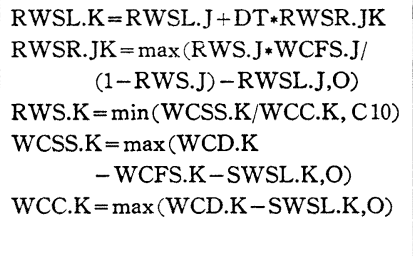 & 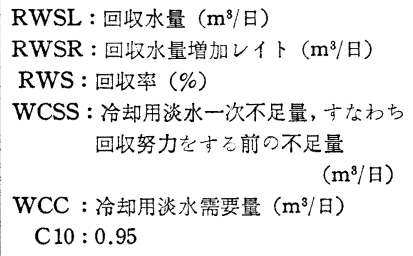 & $\begin{array}{l}\text { 冾却用水の不足量と椧却用淡水需要量の } \\
\text { 比を回収率と考え, 回収率がその值をとれ } \\
\text { ば, 椧却用水の需要は満たされるわけだ } \\
\text { が, 技術上の制約により, } 95 \% \text { を上限值 } \\
\text { とした. }\end{array}$ \\
\hline & $\begin{array}{c}\text { 冷却用淡水 } \\
\text { 供 給 量 } \\
\text { WCF } \\
\text { と椧却用工 } \\
\text { 水利用量 } \\
\text { WCS }\end{array}$ & $\begin{array}{l}\text { WCF.K }=\text { WCFS.K } /(1-\text { RWS.K }) \\
\text { WCS.K }=\text { WCF.K + SWSL.K }\end{array}$ & $\begin{array}{l}\text { WCF : 冷却用淡水供給量 }\left(\mathrm{m}^{3} / \text { 日) }\right. \\
\text { WCS : 冷却用工水利用量 }\left(\mathrm{m}^{3} / \text { 日) }\right.\end{array}$ & \\
\hline
\end{tabular}




\begin{tabular}{|c|c|c|c|c|}
\hline & レベル名 & レベル方程式およびレイト方程式 & 記 号 の 説 明 & 備 \\
\hline 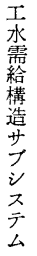 & $\begin{array}{c}\text { 冷却用水 } \\
\text { 最終不足量 } \\
\text { WC }\end{array}$ & $\begin{aligned} \text { WC.K }= & \max (W C D . K \\
& - \text { WCS.K }- \text { WWW.K,O }) \\
\text { WWW.K } & =\text { TITP.K*RUU } \\
\text { TITP.K } & =\text { SWW.K*SL.K } \\
\text { SWW.K } & =\max (W I D . K+W C C . K \\
& - \text { WIS.K*0.06-RWSL.K,O })\end{aligned}$ & $\begin{array}{l}\text { WC : 冷却用最終不足量 }\left(\mathrm{m}^{3} / \text { 日) }\right. \\
\text { WWW : 下水再利用水 }\left(\mathrm{m}^{3} / \text { 日 }\right) \\
\text { TITP : 下水処理場流入量 }\left(\mathrm{m}^{3} / \text { 日) }\right. \\
\text { SWW : 工場排水量 }\left(\mathrm{m}^{3} / \text { 日) }\right. \\
\text { SL : 下水道普及率 }(\%) \\
\text { RUU : 再利用率 }\end{array}$ & 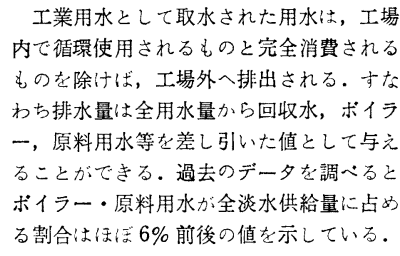 \\
\hline
\end{tabular}

改善の方向：今後は，生産効率の向上に伴5単位出荷額あたりの水使用量の隇少が考えられるので，その効果を導入していく必要がある。また，冷却 用水最終不足量算定の部分はかなり概念的であるので, データの收集をはかっていくとともに，ての実証が必要である.

表一5 水源開発構造のシステム方程式

\begin{tabular}{|c|c|c|c|c|}
\hline & レベル名 & レヘル方程式およびレイト方程式 & 記 号 の 説 明 & 備 \\
\hline $\begin{array}{l}\text { 水 } \\
\text { 源 } \\
\text { 開 } \\
\text { 発 }\end{array}$ & $\begin{array}{c}\text { 水源開発量 } \\
\text { WA }\end{array}$ & 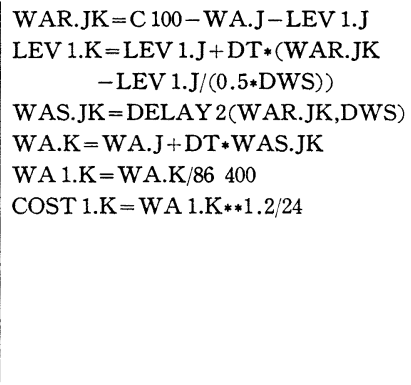 & 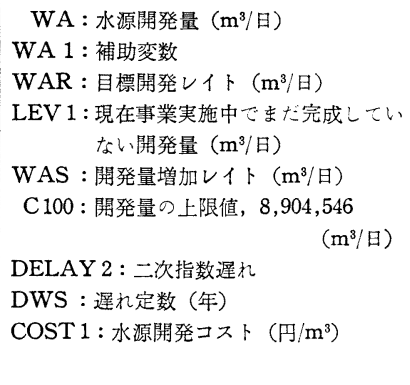 & 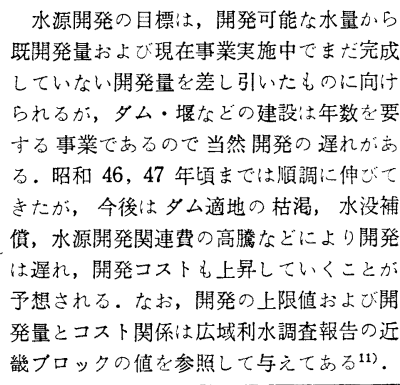 \\
\hline $\begin{array}{l}\text { 構 } \\
\text { 造 } \\
\text { サ } \\
\text { フ } \\
2 \\
\text { ス } \\
\bar{\tau} \\
\text { 厶 }\end{array}$ & $\begin{array}{l}\text { 上 水 道 } \\
\text { 浄 水 量 } \\
\text { BW }\end{array}$ & 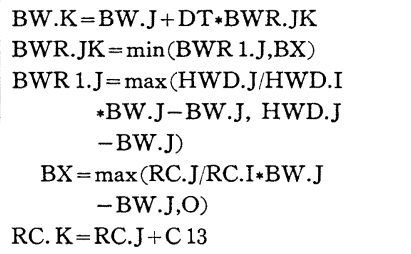 & $\begin{array}{l}\mathrm{BW}: \text { 上水道浄水量 }\left(\mathrm{m}^{3} / \text { 日 }\right) \\
\mathrm{BWR}: \text { 浄水量增加 } 1 卜\left(\mathrm{~m}^{3} / \text { 日 }\right) \\
\mathrm{BWR} 1, \mathrm{BX}: \text { 補助変数 } \\
\mathrm{RC}: \text { 上水管路延長 }(\mathrm{m}) \\
\mathrm{C} 13: \text { 年間の上水管路延長增 }(\mathrm{m})\end{array}$ & 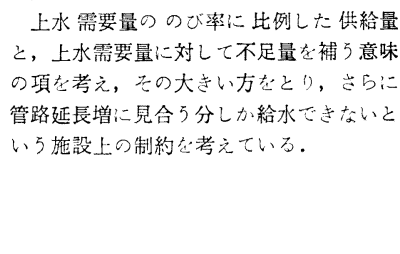 \\
\hline & $\begin{array}{l}\text { 上 水 道 } \\
\text { 取 水 量 } \\
\mathrm{BW} 10 \\
\text { と環境水量 } \\
\mathrm{WE}\end{array}$ & $\begin{aligned} \text { BW } 10 . K=B W . K * 1.1 \\
\text { WE. } K=\text { WA.K }-(W I . K+B W 10 . K): \\
\quad \text { WA.K }>\text { WI.K }+ \text { BW } 10 . K \\
\text { WE.K }=0: \text { WA. } K \leq W I . K+B W 10 . K\end{aligned}$ & $\begin{array}{c}\mathrm{BW} 10 \text { : 上水道取水量 }\left(\mathrm{m}^{3} / \text { 日 }\right) \\
\mathrm{WE}: \text { 環境水量 }\left(\mathrm{m}^{3} / \text { 日 }\right)\end{array}$ & 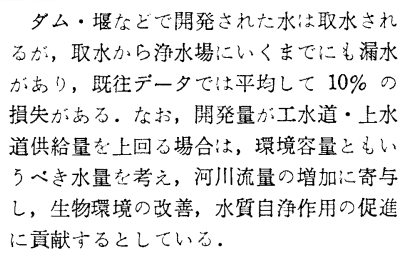 \\
\hline
\end{tabular}

改善の方向：夕厶開発による階段波的增加特性を考慮していくとともに，流入量の平均值だけでなく，その確率特性の導入も必要となってこよう。

ている．また，冷却・温調用水は海水，淡水供給量でま かなわれるが，不足する場合は回収率の向上，さらには 下水処理水の再利用をはかり, それでも不足する場合に は工業出荷額の増加にブレーキがかかると考えられてい る. 表-4 がこの部分のシステム方程式である.

\section{（6）水源開発構造のサブシステム}

この部分では, 湖沼水・河川表流水をダム・堰などの 建設によって開発し, 上水道, 工水道に供給する. な お, 水源開発にはダム適地の枯渇, 水没補償などの問題 があり，開発の遅れおよび開発コストの上昇がみられる ので, モデルではこれらの点も考慮している. 表一5 は これらのシステム方程式である。

\section{（1）水質污濁・処理構造のサブシステム}

上水道用水および工業用水は利用後, 湖沼や河川に排 出され, 公共用水域の水質污濁を覀化させている. ここ では, それを防止すべく処理技術の向上, 下水道の普 及, さらには排出規制をはかっている. また, 水質污濁 は浄化処理コストには齐かえってくるので, コスト面か らの污濁原単位の減少も考えている. なお, 先述したよ うにここでの水質污濁現象は一過性の有機質物質 BOD で代表しており, 蓄積性の污濁物質は考慮の対象外にお いていることを断っておく. 表一6 はこの部分のシステ ム方程式である。 
表一6 水質污濁・処理構造のシステム方程式

\begin{tabular}{|c|c|c|c|c|}
\hline & レベル名 & レベル方程式およびレイト方程式 & 記 号 の 説 明 & 備 \\
\hline & $\begin{array}{l}\text { 生活污濁量 } \\
\text { SPH }\end{array}$ & $\begin{array}{l}\text { SPH.K }=\text { PL.K } * \text { SU.K } \\
\text { SH.K }=\text { SH.J }+ \text { B } 6 \\
\text { SU.K }=\text { SH.K }+ \text { B } 7\end{array}$ & $\begin{array}{l}\mathrm{SPH}: \text { 生活污濁量 }(\mathrm{g} / \text { 日) } \\
\mathrm{SH}: \text { 雑排水污濁原単位 }(\mathrm{g} / \text { 人・日 }) \\
\mathrm{SU}: \text { 生活污濁原単位 }(\mathrm{g} / \text { 人・日 }) \\
\mathrm{B} 6: \text { 雑排水污濁原単位の增加量 } 0.6 \\
\text { (g/人・日) } \\
\mathrm{B} 7: \text { 乙尿污濁量 } 13(\mathrm{~g} / \text { 人・日 })\end{array}$ & 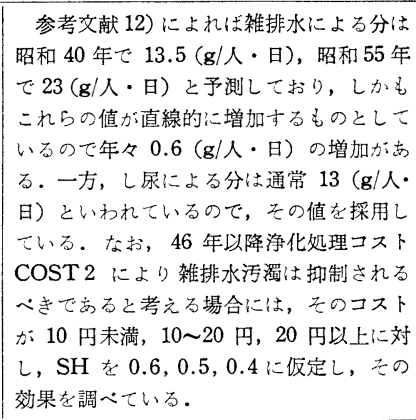 \\
\hline & $\begin{array}{c}\text { 工業污濁量 } \\
\text { SPI }\end{array}$ & \begin{tabular}{|c|} 
SPI.K $=$ WIL.K*SIU.K \\
SIU.K $=$ B $10:$ 排水規制なしの場合 \\
SIU.K $=\max (B 10-\mathrm{A} 10 * \mathrm{~K}, 30): 46$ 年 \\
$\quad$ 以降, 排水規制を実施した場合
\end{tabular} & $\begin{array}{l}\mathrm{SPI}: \text { 工業污濁量（g/日） } \\
\mathrm{SIU}: \text { 工業污濁原単位（g/日・百万円） } \\
\mathrm{B} 10: 112.7 \mathrm{~g} / \text { 日・百万円） } \\
\mathrm{A} 10: 8.14 \text { あるいは } 4.0 \\
\qquad(\mathrm{~g} / \text { 日・百万円 })\end{array}$ & 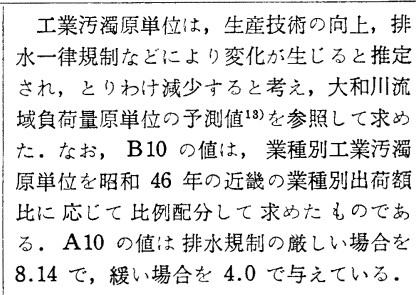 \\
\hline $\begin{array}{l}\text { 水 } \\
\text { 質 } \\
\text { 污 } \\
\text { 濁 } \\
\text { 処 } \\
\text { 理 } \\
\text { 構 } \\
\text { 造 } \\
\text { サ } \\
\text { フ } \\
\text { ン } \\
\text { ス }\end{array}$ & $\begin{array}{l}\text { 生活排水の } \\
\text { 河川放流污 } \\
\text { 濁量 } \\
\quad \text { SPOH }\end{array}$ & 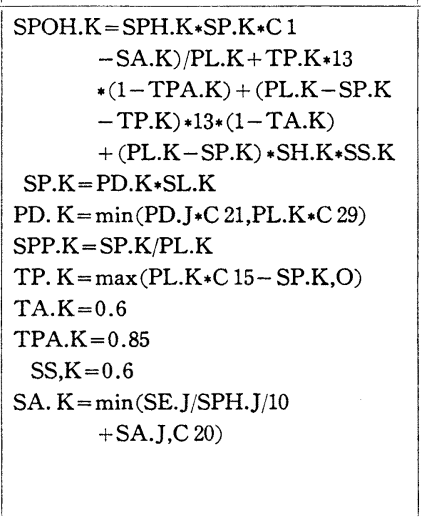 & 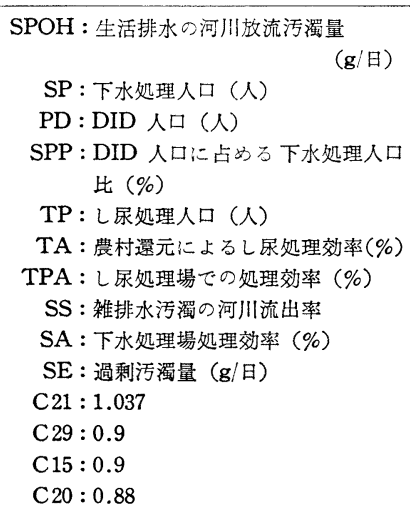 & 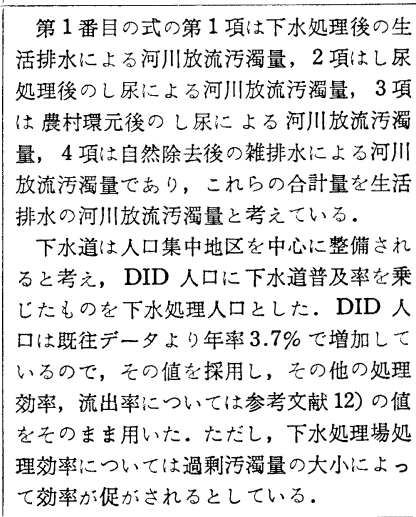 \\
\hline $\begin{array}{l}\text { テ } \\
\text { ム }\end{array}$ & $\begin{array}{l}\text { 工業排水の } \\
\text { 河川放流污 } \\
\text { 濁量 } \\
\quad \text { SPOI }\end{array}$ & $\begin{aligned} \text { SPOI.K }= & \{\text { SI.K } *(1-\text { SIA.K }) \\
& +(1-\text { SI.K }) * \text { SSI.K }\} * \text { SPI.K } \\
\text { SIA.K }= & \min (\text { SE.J } / \text { SPI.J } / 10 \\
& + \text { SIA.J.C } 16) \\
\text { SI.K }= & \text { SL.K } \\
\text { SSI.K }= & 0.6\end{aligned}$ & $\begin{array}{l}\text { SPOI : 工業排水の河川放流污濁量 }(\mathrm{g} / \text { 日) } \\
\text { SI : 污濁物の処理場流入率 }(\%) \\
\text { SSI : 未処理污濁物の河川流出率 }(\%) \\
\text { SIA : 下水処理場処理効率 }(\%) \\
\text { C16 : } 0.8\end{array}$ & $\begin{array}{l}\text { 工業污濁物を処理場に流入するものと, } \\
\text { しないものに分け, それぞれの效率を乗 } \\
\text { し, 河川放流污濁量を求めた，ての他に関 } \\
\text { しては家庭排水の場合と同粎の考えをとっ } \\
\text { ている. }\end{array}$ \\
\hline & 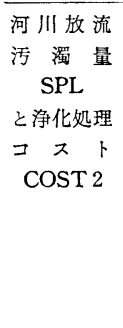 & $\begin{array}{l}\text { SPL.K }=(\text { SPOH.K }+ \text { SPOI.K }) * 0.9: \\
\text { WE.K }<10^{6} \\
\text { SPL.K }=(\text { SPOH.K }+ \text { SPOI.K }) * 0.8: \\
\text { WE.K } \geq 10^{8} \\
\text { SPLI.K }=\text { SPL.K } / 43401915 \\
\text { COST } 2 . \mathrm{K}=1.5 * \text { SPL } 1 . K-3.0: \\
\text { SPL } 1 . K \geq 2 \\
\text { COST } 2 . \mathrm{K}=0: \text { SPL } 1 . \mathrm{K}<2\end{array}$ & $\begin{array}{l}\text { SPL : 河川放流污濁量 }(\mathrm{g} / \text { 日 }) \\
\text { SPL } 1: \text { 補助変数 } \\
\operatorname{COST} 2: \text { 捸化処理コスト }\left(\text { 円 } / \mathrm{m}^{3}\right)\end{array}$ & 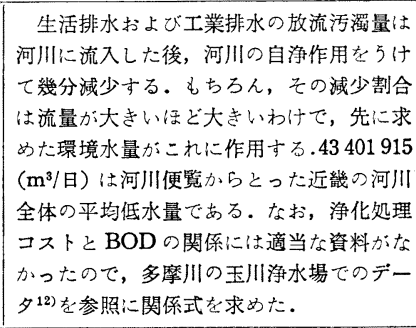 \\
\hline & $\begin{array}{l}\text { 環 境 基 準 } \\
\mathrm{ED} \\
\text { 之過剩污濁 } \\
\text { 量 } \\
\mathrm{SE}\end{array}$ & $\begin{aligned} \text { ED. } \mathrm{K}= & 13.02 * 10^{7}(3 \mathrm{ppm} \text { に相当 }) \text { あるい } \\
& \text { は } 86.8 * 10^{7}(20 \mathrm{ppm} \text { に相当 }) \\
\mathrm{SE} . \mathrm{K}= & \max (\mathrm{SPL} . \mathrm{K}-\mathrm{ED} . \mathrm{K}, 0)\end{aligned}$ & $\begin{array}{l}\mathrm{ED}: \text { 環境基準あるいは水質基染 ( }(\mathrm{g} / \text { 日) } \\
\mathrm{SE}: \text { 過剩污濁量 }(\mathrm{g} / \text { 日) }\end{array}$ & 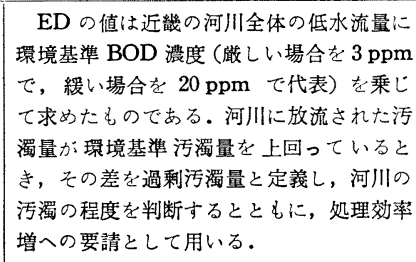 \\
\hline
\end{tabular}




\begin{tabular}{|c|c|c|c|c|}
\hline & レベル名 & レベル方程式およびレイト方程式 & 鱾 号 の 説 明 & 考 \\
\hline 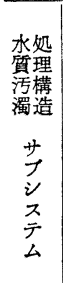 & \begin{tabular}{|lll} 
下 & 水 & 道 \\
普 & 及 & 率 \\
& $\mathrm{SL}$ &
\end{tabular} & $\begin{aligned} \text { SR.JK }= & \text { C } 18-\text { SL.J-LEV } 3 . J \\
\text { LEV } 3 . \mathrm{K} & =\text { LEV } 3 . J+D T *(S R . J K \\
& - \text { LEV } 3 . J /(0.5 * D E L)) \\
\text { SDR,JK } & =\text { DELAY } 2(\text { SR.JK,DEL }) \\
\text { SL.K } & =\text { SL.J + DT } * \text { SDR.JK }\end{aligned}$ & $\begin{aligned} \text { SL : 下水道普及率 (DID 人口に対し } \\
\text { て \%) } \\
\text { LEV } 3: \text { 現在事業実施中でまた完成してい } \\
\text { ない下水道容量 (\%) } \\
\text { SDR : 下水道普及率増加レイト (\%) } \\
\text { DELAY } 2: \text { 二次指数遅れ } \\
\text { DEL : 遲れ定数 (年) } \\
\text { C18 }: 0.9\end{aligned}$ & 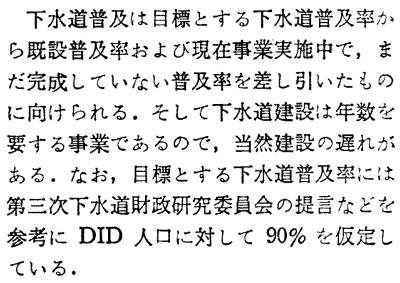 \\
\hline
\end{tabular}

改善の方向：工業污濁量の算定において，大和川流域負荷量原単位の予测值を近畿圈全体に代用することはやや問題がある。おた，この部分はより籍 密には，業種別工業污濁原単位とその出荷額との積の和で，工業污濁量を評価すへきである5．BOD 值は近畿圈全体の平均値というこ とであるか，実際には，河川流量の変動，各河川の流量とその河川ての排水量との間で，これらの算出をして，たとえば, 流域面積で除 すとかの手順を皂むへきであらう。 L尿処理と下水処理, 家庭排水処理と工業排水処理, これらの合成処理および分離処理の実態を考感 していく必要がある。本モデルでは分離処理を望ましい处理法として採用しているが。

表一7 工業出荷額のシステム方程式

\begin{tabular}{|c|c|c|c|c|}
\hline & レペル名 & レベル方程式およびレイト方程式 & 記 号 の 説 明 & 備 \\
\hline 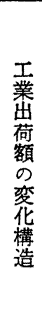 & \begin{tabular}{|c} 
工業出荷額 \\
WIL
\end{tabular} & 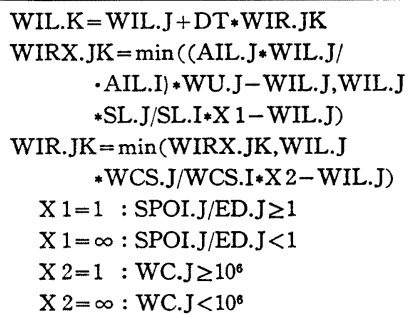 & $\begin{array}{l}\text { WIL : 工業出荷額（百万円） } \\
\text { WIRX : 補助変数 } \\
\text { WIR : 工業出荷額変化レイト（百万円） } \\
\text { WU : 技術レヘルル向上にともなう土地原 } \\
\quad \text { 単位割增係数 }\end{array}$ & 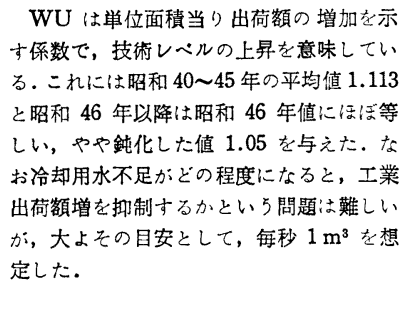 \\
\hline
\end{tabular}

改善の方向：工業出荷額変化レイトがこれらの因子によって影響を受ける程度がっとも問題となる，すなわち、これらの抑制か直接, 工業出荷額 增に影䇾を及济すかである。実續值の增淢を十分検討し，より実際的な内生化をはかっていく必要がある。どうしても困難とならば工業 成長率といった，いわゆる外生变数的取扱いが必要になってこよ5が, それでは水資源そのものが，従来とあまりかわらない評価づけに 甘んじなければならないことになる。

\section{(8) トータルシステム}

以上, 各サブシステムの構造をシステム方程式で構成 したが，これらサブシステムを結ぶもっとも重要なレイ トは工業出荷額変化レイトである.これには以下のよう な 3 つの值を求め, そのうち最小のもので意志決定し た.すなわち, 1 番目は事業所敷地面積に対する出荷額 で，土地原単位をもとにして求めるが，土地原単位も技 術レベルの向上で変化する. 2 番目は水質污濁による出 荷額へのフィードバックで, 特に昭和 50 年以降は水質 基準許容污濁量を工業の河川放流污濁量が上回ると制約 として働き，出荷額は下水道普及率の伸び以上には伸び なくなるとする． 3 番目は泠却用水の不足が生じると制 約として効いてくるもので, 冷却用水供給量ののび以上 には伸びなくなると考える．このことは，工業用水で出 荷額増と関連して伸びてくる用途は泠却用であり，また 冷却用の他の用途と違い，回収や海水の利用が可能であ るので，新規水源の確保が他の用途に比べて 容易であ る.つまり出荷額と結びつきが強く，しかも新規利水に 柔軟性のある冷却用水を重視したわけである.

したがって，工業出荷額のレベル方程式およびレイト 方程式は表一7で与えられる.
以上，述べてきたサブシステムを一つにまとめたもの がトータルシステムになるわけで, フローダイアグラム で示寸と図一4のようになる. なお，定数の記入は図を はん雑にするので省いている. 図中で種々の流れをつな ぎあわせて閉回路を構成しているものが SD でいうイ ンフォメーション・フィードバック・ループであり, 重 要なものを図の下に列挙しておく.

\section{5. シミュレーション結果の考察および水需給 構造の将来の展望}

\section{(1) 政策変数}

まず, シミュレーションに際して与えてやるべき政策 変数をまとめて記しておく.

a) 水源開発の進渉度 (DWS)

ダム適地の 枯晹, 補償問題などに伴い水源開発は遅 れ，そのコストも上昇している.ここではこれらの効果 を水源開発遅れ定数 DWS に集約させ，末開発可能量 C 100 を $30,50,100$ 年の年月を要して開発すると考え た.

b）下水道普及の進渉度（DEL） 


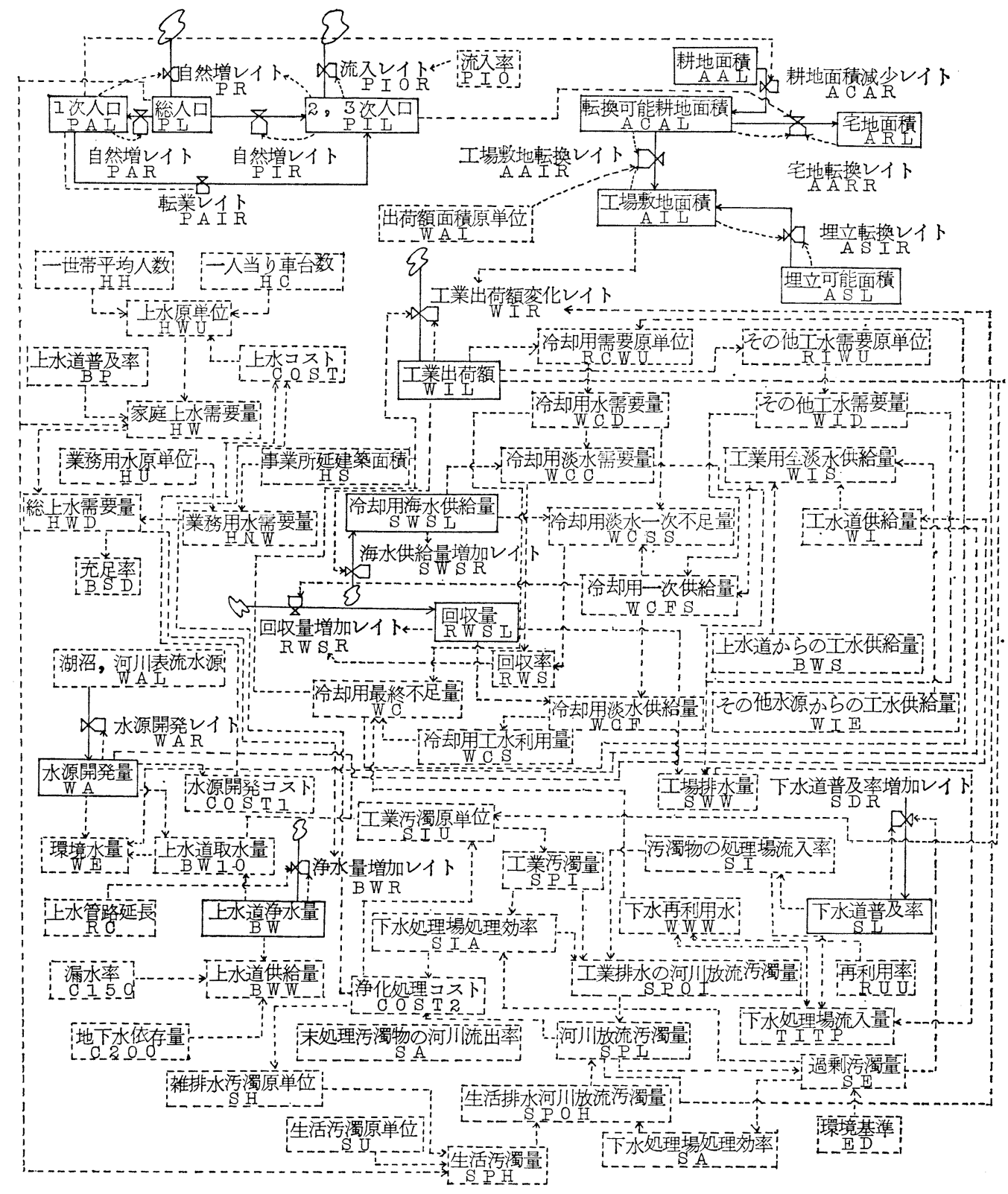

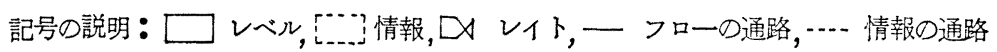

1）上水原単位 $\longrightarrow$ 上水需要 $\longrightarrow$ 節水淬 与供給促進 ${ }^{\uparrow} \longrightarrow$ 策 2) 工業出荷額 $\rightarrow$ 工業污蜀原単位 $\rightarrow$ 工業污濁量 $\underset{\uparrow}{\longrightarrow}$ 河川倣流污濁量 $\longrightarrow$ 浄化処理コスト 下水道普及率・処理效率上過剩污濁量

3.) 工業出荷額 $\rightarrow$ 冷却用原単位 $\longrightarrow$ 椧却用需要量 —下水处理水再利用 $\longrightarrow$ 最終不足量

4）工業出荷額 $\rightarrow$ 土地原単位 $\rightarrow$ 工場敷地面積 
下水道普及も緊急を要する問題であるが, 現実には困 難をきわめている. この進渉度を下水道普及率遅れ定数 DEL で表現し, 目標普及率 C 18 に達するのに 30,50 , 100 年を要するとしている.

c) 上水管敷設の進渉度 (C 13)

過去のデー夕は $2000 \mathrm{~km} /$ 年の上水管路延長を示して いるが，47 年はその延長距離が短くなっている.ここ では今後とも $2000 \mathrm{~km} /$ 年 で伸ばすべき，今後は 1000 $\mathrm{km} /$ 年で伸びていく, の 2 ケースを考元，上水供給をは かっている.

\section{d）環境基準あるいは水質基準 (ED)}

公共用水域の水質悪化は種々の幣害をもたらしている が，ここでは BOD 指標で代表させ， 46 年以前は 20 $\mathrm{ppm}, 47$ 年以降は厳しく $3 \mathrm{ppm}$ にする場合と, 緩い 20 ppm の両者を考えた.

e) 再利用率 (RUU)

下水处理場からの再利用水は今後の処理技術の向上に 伴い, 慢性的な水不足の対症療法的な手段として脚光を あびているが，現実には抵抗感も強い。ここでは今後と も再利用注行われない，段階的に再利用が進められる (50 55 年: $10 \%, 55$ 年以降: $20 \%)$ の 2 ケースを考 える.

f) 漏 水率 (C 150)

多額の投資をして開発された水も，取水・浄水・配水 系統の過程で漏水する. 水の合理的利用を考える以上, 漏水防止策は必要であるが，完全には防止できないであ 万ら。ここでは今後とも $20 \%$ の漏水はある，防止策を 講じて段階的に漏水率を隇らす（50 55 年: $15 \%, 55$ 年以降: 10\%）の 2 ケースを考えている.

g）企業努力・行政指導による污濁原単位の減少

(SIU)

企業の種類，規模などによって污濁原単位は多種多様 であるが，公共水域の水質污濁の根源といわれている以 上，何らかの形で污濁原単位の減少をはからなければな らない。ここでは今後とも污濁原単位は減少しない，46 年以降は企業努力, 行政指導などにより原単位を厳しく 減らす (年減少割合 $8.14 \mathrm{~g} /$ 年), 緩いが減らす (年減少 割合 $(4.0 \mathrm{~g} /$ 年) の 3 ケースを考えた。

h) 企業努力による用水原単位の減少 (RCWU)

冷却・温調用水に限り，不足量が 10 万 $\mathrm{m}^{3} /$ 日以上にな ると企業努力によって用水原単位が 10\% 減ると考えた。

i）上水コストによる上水原単位，污濁原単位の減少 (D 1, D 3, D 4, B 6)

企業が海水利用, 回収率の向上, 下水処理水の再利用 などによって用水需要をまかなう一方，污濁原単位も減 ら寸努力をしている以上，上水需要者も何らかの形で水 不足，水質污濁に対処しなければならない，ここでは水
表一8 シミュレーション No.（政策変数の組合せ）

\begin{tabular}{|c|c|c|c|c|c|c|c|c|c|}
\hline 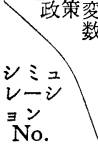 & $\begin{array}{l}\text { 水 } \\
\text { 源 } \\
\text { 開 } \\
\text { 発 }\end{array}$ & $\begin{array}{l}\text { 下 } \\
\text { 水 } \\
\text { 道 } \\
\text { 普 } \\
\text { 多 }\end{array}$ & $\begin{array}{l}\text { 卡 } \\
\text { 永 } \\
\text { 管 } \\
\text { 唇 } \\
\text { 長 }\end{array}$ & $\begin{array}{l}\text { 水 } \\
\text { 貿 } \\
\text { 基 } \\
\text { 渵 }\end{array}$ & 用 & $\begin{array}{l}\text { 漏 } \\
\text { 水 } \\
\text { 防 } \\
\text { 止 }\end{array}$ & $\begin{array}{l}\text { 工原 } \\
\text { 水単 } \\
\text { 污位 } \\
\text { 濁娍 }\end{array}$ & $\begin{array}{l}\text { 采 } \\
\text { 原 } \\
\text { 単 } \\
\text { 泣 } \\
\text { 減 }\end{array}$ & $\begin{array}{l}\text { 上効 } \\
\text { 水 } \\
\text { ב } \\
\text { 天 } \\
\text { 卜果 }\end{array}$ \\
\hline 1 & 遅 & 遲 & 遅 & 酷 & $x$ & $x$ & $x$ & $x$ & $x$ \\
\hline 2 & 遅 & 漣 & 遲 & 緩 & $x$ & $x$ & $x$ & $x$ & $x$ \\
\hline 3 & 遅 & 急 & 遅 & 緩 & $x$ & $\times$ & $x$ & $x$ & $x$ \\
\hline 4 & 急 & 急 & 急 & 緩 & $x$ & $x$ & $x$ & $x$ & $x$ \\
\hline 5 & 遅 & 急 & 遅 & 慰 & $x$ & $x$ & $x$ & $x$ & $x$ \\
\hline 6 & 急 & 急 & 急 & 撖 & $x$ & $x$ & $x$ & $x$ & $x$ \\
\hline 7 & 遅 & 遅 & 遅 & 緩 & 0 & 0 & 厳 & 0 & 0 \\
\hline 8 & 趛 & 逑 & 達 & 厳 & 0 & 0 & 䈌 & 0 & 0 \\
\hline 9 & 急 & 急 & 急 & 䉷 & 0 & 0 & 旋 & 0 & 0 \\
\hline 10 & 遅 & 遅 & 遅 & 単 & 0 & 0 & 繯 & 0 & 0 \\
\hline 11 & 遅 & 暑 & 遅 & 笡 & 0 & 0 & 厳 & 0 & 0 \\
\hline 12 & 急 & 急 & 急 & 綏 & 0 & 0 & 厳 & 0 & 0 \\
\hline 13 & 早 & 早 & 早 & 撖 & $x$ & $x$ & $x$ & $x$ & $x$ \\
\hline 14 & 早 & 早 & 早 & 緩 & $x$ & $x$ & $\times$ & $x$ & $x$ \\
\hline 15 & 早 & 急 & 早 & 啟 & $x$ & $x$ & $x$ & $x$ & $x$ \\
\hline 16 & 早 & 早 & 早 & 笅 & 0 & 0 & 簏 & 0 & 0 \\
\hline 17 & 早 & 早 & 早 & 緩 & 0 & 0 & 厳 & 0 & 0 \\
\hline 18 & 早 & 早 & 早 & 旋 & 0 & 0 & 䈆 & 0 & $x$ \\
\hline 19 & 早 & 早 & 早 & 旋 & 0 & 0 & 䌅 & 0 & 0 \\
\hline
\end{tabular}

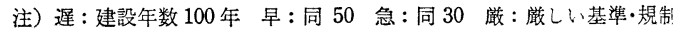
緩：緩い基淘・規制 $\bigcirc$ : 採用 $x$ : 不探用

源開発コスト，浄化処理コストなどに伴う上水コストの 上昇により需要者が原単位を減らす努力をする，しない の両者を考えてシミュレートした。

以上の政策変数を組み合わせば，非常に多くのシミュ レーション・ランが可能であるが，本研究では特徵的な 水需給構造の将来をさぐる意味で, 表一8 に示す 19 通 りのシミュレーション・ランに限って考察した。

\section{（2）モデルの実証}

次にシミュレーション・ランにあたっては，各レベル および補助変数の初期值を与えなければならない.モデ ルの構成上, 初年度の昭和 40 年のみの值と, 昭和 39 年 と 40 年の両年の值を必要とするものがあり，これらの 值を一括して表一9に示す.

このように初期值が与えられ, シミュレーションの単 位時間 DT が 1 年にとられると，4.で構成した SD モ デルによって, 各レベルの值が 1 年ごとにシミュレート される.この場合，シミュレーション結果が少なくとも データの存在する期間で実測值と合致するように SD モ デルの構造および定数を修正し，モデルそのものの実証 をはかる必要がある. 本モデルでは昭和 40 46 年をこ の実証期間とし，この期間モデルの改善をはかり，すで に 4. で述べたシステム方程式および各定数を採用した わけである.

図一5，6 は代表的なレベルについて，40〜46 年を training 期間, 47〜50 年を checking 期間とみなして, シミュレーション結果と実績值を比較したものである. 


\section{表一9 シミュレーションに用いた初期值}

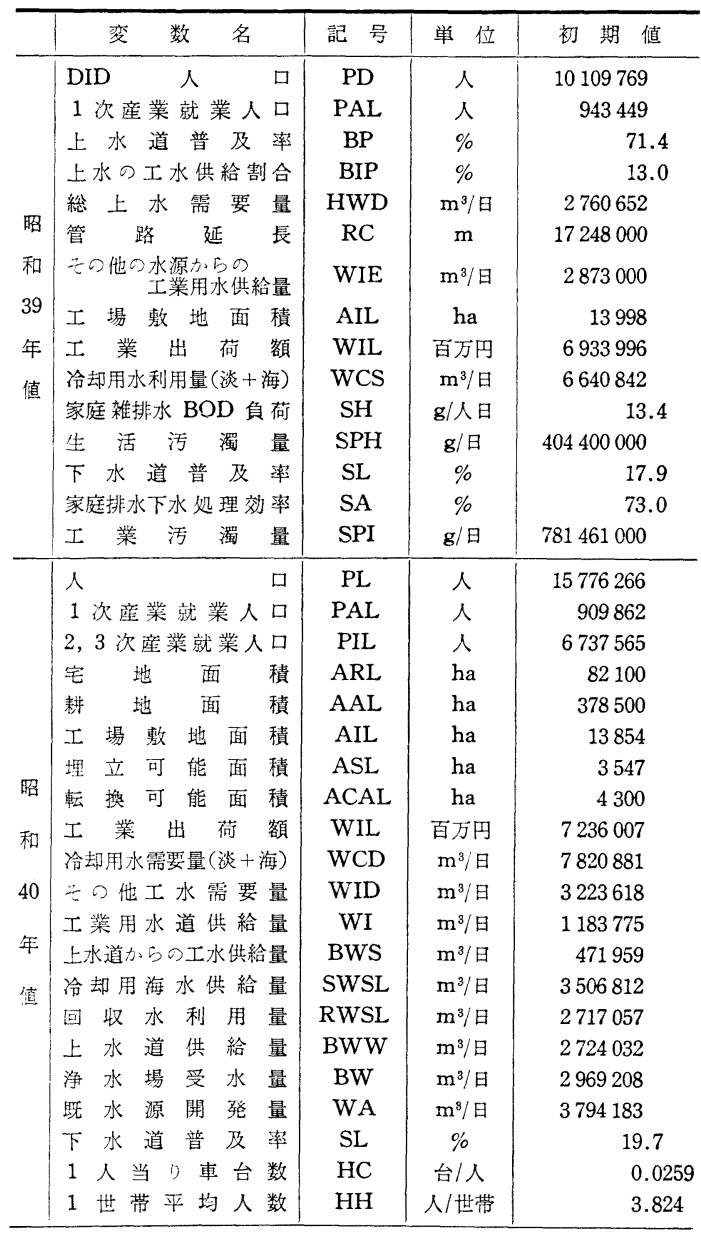

training 期間につ いていえば，両者 はほぼ合致してい る. 実際に汇近畿 圈といえどもそそ の内部では各レべ ルともかなり地域 分布性を有してい るが，モデルでは 平均操作をしてい る.また，システ 么方程式を構成す る各パラメーター の決定に際しては 必然的に回帰誤差 が伴って扔り,こ れら平均操作に伴 う誤差および回帰

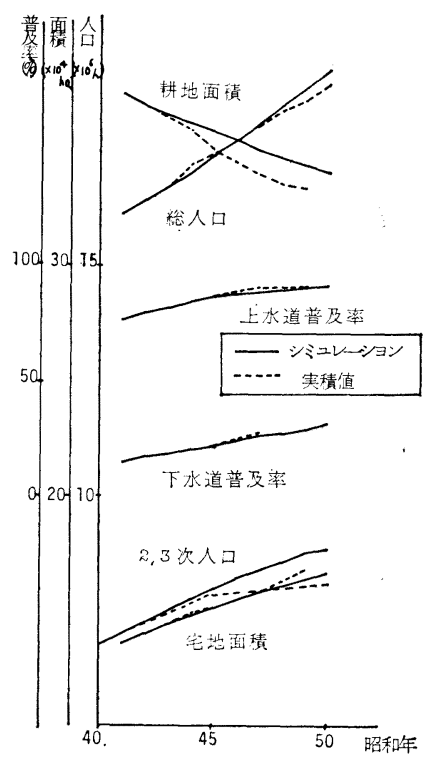

図一5 モデルの実証例
誤差などを考えると， training 期間での実証性 は十分高いと判断でき る. 一方, checking 期 間に㧍いては傾向特性は 再現しているが，絶対值 評価でみると，シミュレ ーション結果と実績值の かい離の大きいレベルが いくつか見受けられる.

特に工業出荷額ののびは 鈍化しておらず，世にい う安定成長, 環境破壊に 対する抑制，これらの効 果をモデルで強調したき らいがあるし，工業出荷 額の水需給構造による内 生化には，現時点ではま だ問題があるようであ る。

\section{しかし, 複雑な水需給}

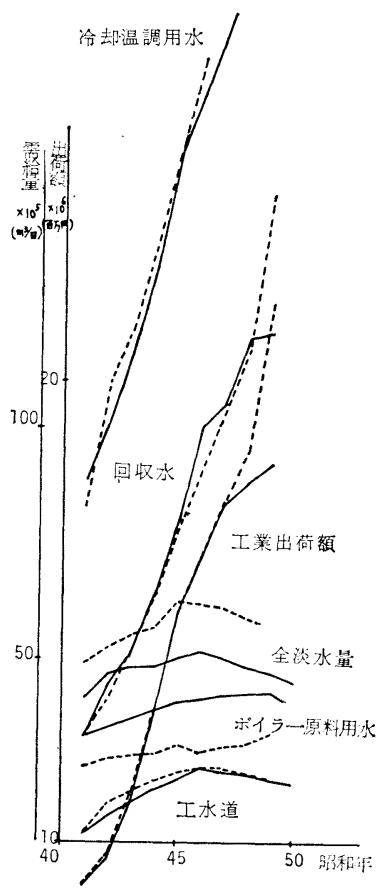

図一6 モデルの実証例
構造とその挙動をマク口的汇把握・予測するという立 場, 量・質・コストからくるフィードバック機構の導入 はいままではあまり効かなかったが，今後 50 年以降は 効いてくるであろうし，効かすべきであるという立場， システム方程式構成の際介入してくる詿差の是認, これ らの立場をとるならば，本モデルによるシミニレーショ ン結果の分析は, 今後の水需給構造を展望するうえで大 いに意義あるものと考えられる。

なお，以下のシミュレーションの中で重要な役割を占 める工業出荷額については，卸売物価指数を用いて 45 年価格江換算した実質額を採用している。 また，シミュ レーション沿和 70 年までとしている. 70 年以降の遠 い将来の経済活動，技術革新などの予測にはいままで以 上に多くの不確実性が介在して扔り，本研究で展開した システム方程式の構成および内容の信ぴょう性がさらに 問題になると考えたからである.

\section{（3）シミュレーション結果}

19 通りのシミュレーション結果が各レベルについて 得られるが，紙面の都合上，特徽的なシミュレーション として No. 1 と No. 9 のみの結果を図一7,8 亿示し, 他のシミュレーション結果とあわせた考察汁 5. (4) で述 べる.ここに No. 1 は水源開発, 下水道普及, 上水管 路延長とも遅々として進まず，しかも企業や個人も用水 原単位, 污濁原単位を減らす努力をしない場合のシミュ レーション・ランで, 水質基準は 46 年以降 $3 \mathrm{ppm} に$ 


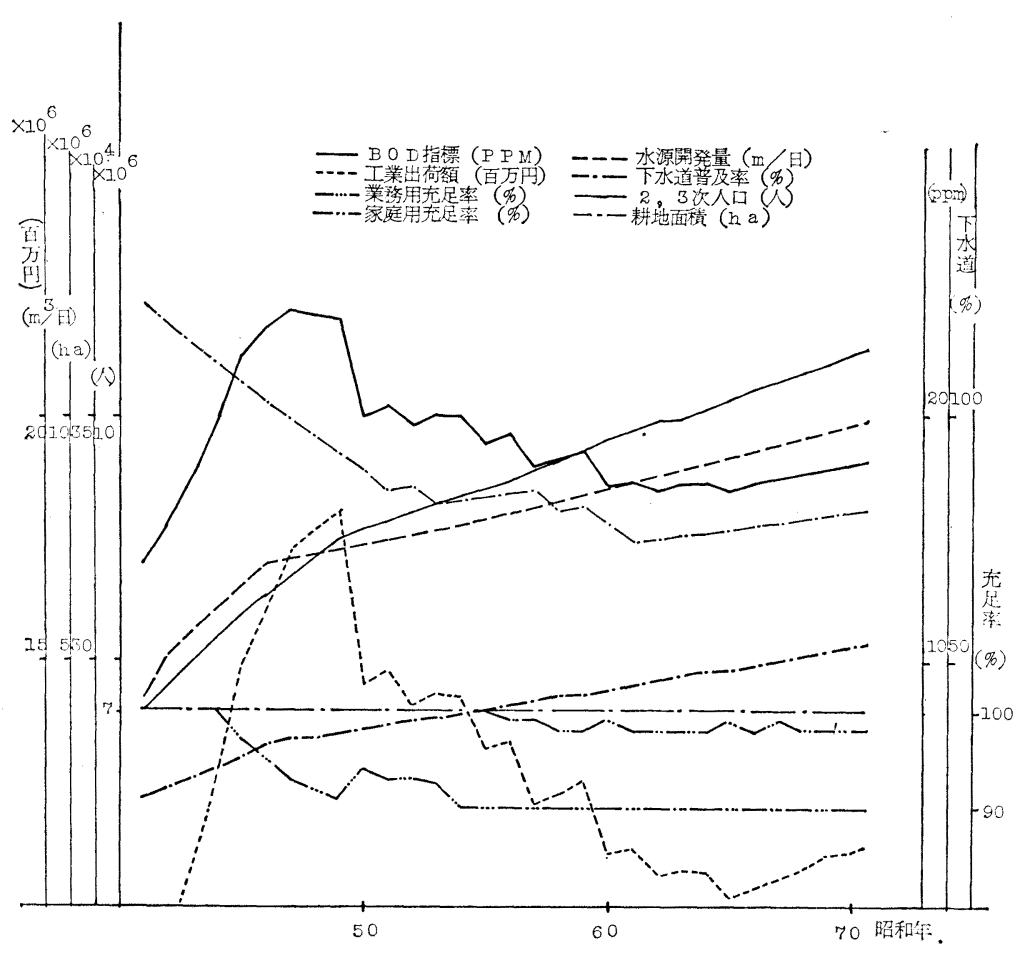

図一7 シミュレーション結果の一例 (No. 1)

おさえてある.また, No. 9 は 水源開発, 下水道普及, 上水管 路延長とも 46 年までの状況と 同様, 順調に進捗し, しかも再 利用, 漏水防止がはかられ, 用 水原単位・污濁原単位を減らす 努力も払われる場合で，もちろ ん水質基準は蕨しく $3 \mathrm{ppm}$ に おさえている。

\section{(4) 結果に対する考察}

他のシミュレーション結果と もあわせ, 工業出荷額, 充足 率, $\mathrm{BOD}$ 指標の変化交中心に 考察する.

\section{a）工業出荷額}

水源開発の速度がかなり出荷 額パターンに影響を及ぼしてい る.すなわち，遅々として進ま ないと出荷額は 50 年以降てい 減し, そのてい減は 60 年半ば まで続き, その後は徐々に増加 する. 水源が昭和 70 年くらい で開発し尽くされる, いわゆる開発が急ピッチ で進められる場合には，49 年に若干の落込み はあるが，50 年代は急上昇し，60 年代に入る と全体的に増加して増減の振幅が激しい不安定 成長を呈している.両者の中間の開発速度で開 発し尽くされる場合には，50 年以降上昇し， しかもその上昇傾向はその後も続き，比較的安 定した成長を示している。

環境基準あるいは水質基準も工業出荷額汇影 響を及ぼしている.すなわち, 水質基準が厳し いと出荷額レイトにフィードバックする傾向が 強く，緩いと規制が働かない，したがって他の 条件が同一であれば，水質基準の緩い方が工業 出荷額の増加に寄与しているが，環境の悪化を 代償にしての出荷額増であることはま妨れな い.

そのほか, 漏水防止, 再利用, 企業努力によ る用水・污濁原単位の減少, コス卜作用による 用水原単位減少も用水不足, 水質污濁を緩和さ せることを通じて, 出荷額増に寄与している. ただ，これらの寄与率は水源開発，水質基準に 比べると小さい.

また，下水道普及率は上限に達してしまうと 水質規制の厳しさともあいまって, 出荷額を停 
滞させている.

b) 充 足 率

全期間，業務用・家庭用とも充足されるのは No. 9， $16,18,19$ の 4 ケースであり, 水源開発および下水道普 及が少なくとも 30 年あるいは 50 年のピッチで，また 上水管路延長もそれに相応して進められることが必要で ある.しかし，こうした施設の建設だけでは両者の充足 は難しく, 厳しい水質基準, 漏水防止, 再利用の促進, 企業の用水・污濁原単位減少, コスト作用による用水原 単位減少, などの補完があってはじめて可能である.ち なみに水源開発が急ピッチであっても, 水質規制が甘い と工業出荷額の急激な増加をまねき, 業務用需要を増大 させ, 終局的には節水を余儀なくされている. また, 水 源開発が遅々として進まない場合には家庭用にまで節水 を課しているが, 漏水防止, 再利用の促進, 企業努力お よびコスト効果の採用は家庭用だけは充足させている.

しかも，これらの規制・努力は節水率を緩和させる方向 に作用している.

c) BOD 指標

いずれのシミニレーション結果も $3 \mathrm{ppm}$ を下回るこ とはなかったが，いくつかの変化を示している． BOD 指標の変化には下水道普及率, 水質基準および企業努 力・行政指導による排出規制が大きく影響している. 水 源開発も環境用水を生み出すほど開発されると自浄効果 を発揮するが，一方では工業出荷額を増加させることか ら污罍物を多量に河川に放出する負の效果ももってい る.もちろん，これらが有機的に組み合わされると， BOD 指標はもっとも好転し, $10 \mathrm{ppm}$ を下回る.

水質基準の厳しいことが出荷額へのはねかえりを通じ て BOD 指標を低く抑えるようであり, 下水道普及は処 理効率に, 排出規制は污濁原単位減に, 水源開発は環境 用水の自浄効果にそれぞれ作用して BOD 指標の低下に 寄与しており, その寄与率は水質基準がもっとも大きい ように思われる. しかし, 下水道普及, 排出規制の効果 もあるので, 従前以上に努力をしなければならない。 ち なみに排出規制をやや緩和すると，50 年代，60 年代の BOD 低減を緩めることになっているし, さらにこれら 4 条件が最悪に組み合わされると，たえず $20 \mathrm{ppm}$ を越 える事態も招きかねない.

\section{（5）今後の水需給構造の改善方向}

以上のシミュレーション結果にあらわれた動向をふま えるならば, 以下のような水需給構造の改善方向が描け よう.

すなわち，単独の政策手段によっては，1）産業の生 産・管理環境の拡大, 2) 工業出荷額の長期的かつ安定 的成長，3）家庭・業務用水の充足，4）公共用水域の水
質指標の改善, これらすべてを満たすことはできない. 個々の手段はそれなりに個々の目的を達成するように貢 献はするが，決して究極的な解決策とはならない，本モ デルで考察した限りでは, 究極的な解決策とはいえない までも，水源開発・下水道普及および上水管路延長にみ られる諸施設の建設をすみやかに進めるとともに，水質 基準を厳しく敷き，漏水防止，下水の再利用，企業努 力・行政指導による用水・污濁原単位の減少, 上水コス トによる用水原単位の減少, これらすべてを組み合わせ ることが現時点で講じるべき水需給政策の基本であろう と思われる.

ただ 5. (4) でも考察したように, 水源開発を急ピッチ にし, 水質基準を緩くしても出荷額の上昇は期待される が, 50 年, 60 年代で上昇し尽し, それ以降の増加が鈍 化したり，水質指標そのものが悪化したりする.また， これら諸施設の進捗度は早い方が遅いよりもいいが，そ れらのいずれかが早かったり遅かったりでは施設間の有 機的な連係が保持されず，かえって悪い結果をもたらし か叔ないので，これらの点を考慮しながら施設建設を進 めていかなければならない.

なお，下水の再利用が叫ばれているが，本モデルでは 工業用水を対象とし, その再利用率も20\%にとどめて いるのでその効果は顕著に現われていない，今後は水洗 便所用水・洗車用水などに家庭下水処理後の中質水を配 水することも考えられ，量的には多くなろらが，一方で は 2 元配水による多額の投資, 嫌恶感, 再利用水が工業 出荷額を通じて循環的に污濁排水源になること，などを 考えると問題点も多い.

また，企業努力・行政指導による污濁原単位の減少は 今後とも厳重にはかられるべきであり，上水原単位の減 少も企業の回収努力, 用水原単位減少努力を考えるなら ば，上水コストで強制しなくても浪費をいましめるべき である.ここでは上水コストによる用水原単位の減少効 果を考えており，モデルに導入した定数はかなり概念的 なものではあるが，その効果が水需給構造に少なからず 作用している.このことは施設群によるハード効果はも ちろん, こうしたソフト効果も水需給構造に作用させて いかなければならないことを意味していよう。

最後に, ソフト効果でも水質基準の設定は大きな効果 を及ぼしている．出荷額の急激な上昇を環境悪化を代償 にしてうるよりは，両者の調和した発展を確保する意味 でも水質基準は厳しくされるよう万全を尽すべきであ る.

\section{6. あ とがき}

本研究は水需給構造を一つの社会システムとしてとら 
え，その階層的構造の把握・予測にシステム・ダイナ ミックスを適用したものである.すなわち, 水需給構造 を人口, 土地, 上水需給, 工水需給, 水源開発, 排水污 濁・処理構造の各サブシステムに分解し, フィードバッ ク機構を考慮したシステム方程式を組み立て，いくつか の政策変数を組み合わせたシミュレーションを行うこと によって, 水を中心とした社会構造の将来を探ったもの である. 以下, 本研究で得られた成果を要約すると次の ようである。

（1）工業用水とくに冷却・温調用水の供給は将来ま すます回収水, 海水に依存する傾向を示し, 工水道，上 水余剩水，その他 水源などによる淡水供給量は ボイラ 一，原料，洗浄・処理水をまかなうにすぎない，した がって, 回収水, 海水の利用・拡大がなければ工水不足 をまねき，工業出荷額の停滞さらには減少をまねこう。

（2）工業成長が続くかぎり，1 次産業就業人口は減 少し, それが $2 \cdot 3$ 次産業就業人口を増加させるととも に, 耕地面積の減少を通じて宅地面積, 事業所敷地面積 の増加をもたらす．だが，工業成長が停滞気味になる と，企業の技術レベルの向上で単位面積あたりの工業出 荷額は増加するものの, 事業所敷地の確保が停滞気味に なり, 再び工業出荷額の増加が抑制される。

（3）水源開発の進渉度は工業出荷額の増加に大きな 影響をもたらすが，安定した成長を継続させるためには 急ピッチでありさえす机よ゙よというものではなく，下 水道普及，上水管路の建設と関連させて開発すべきであ り，しかも厳しい水質基準の設定があわせて必要であ る.

（4）工業出荷額の増加, 上水需要の充足, 水質指標 の改善をあわせ汸るるためには, 水源開発・下水道・上 水管路延長といったハードな施設群のすみやかな建設は もとより，厳しい水質基準，漏水防止，下水再利用，企 業努力・行政指導による用水・污濁原単位の減少, 上水 コストによる用水・污濁原単位の減少といったどちらか といえばソフトな面での努力も必要である.

そのほか，いくつかの成果が得られたが，結局，健全 な水需給の発展をはかるには, 個々の政策変数がシステ ム全体に及ぼす影響を十分に認識した上で，それらのシ ステム内における有機的な関連性を追求することによ。 て，はじめて最適な政策が生み出されるといえよう。こ うした意味で, 本モデルでの政策提言として，

（5）回収努力，海水利用の促進はもとより，水源開 発，下水道普及，上水管路延長にみられる諸施設の有機 的関連のもとでの建設促進，厳しい水質基準，漏水防 止, 下水の再利用, 企業努力・行政指導に上る用水・污 濁原単位の減少，上水コストによる用水・污濁原単位の 減少これらすべてを組み合わせた政策手段を講じるこ
とが, 工業成長の安定的かつ長期的な発展の維持, 工水 不足の緩和，上水の充足 $100 \%$ ，水質指標の $10 \mathrm{ppm}$ 以 下への改善，これらすべてを満たしてくれよう。もちろ $几$ ，低成長，節水，環境悪化をある程度許すならば，こ れらすべての厳しい組合せは幾分緩和されょう。

なお，今後の検討課題としては，

（1） システムをコントロールするレイトやフィード バックループに関してさらに研究し, システムの改善に 努力することにより精度の向上をめざす．改善の方向に ついては 表一1〜7 中に一部併記している.

（2）水資源のクローズドシステム化を追求する一つ の方法論を展開することに重点をおいたので，大胆な仮 定やマク口的な計算法を用いたが，それらに対する妥当 性の検討を行う必要がある. Training data, Checking data との比較・考証を通じて一部検討しているが,デー タの蓄積ともあいまって，今後とも検討していきたい。

（3）近畿圈をさらに地域分割し，地域内部㧍よびそ れら地域間相互の水需給構造についいても議論を発展さ せたい。

最後に，本研究を進めるにあたり，資料収集，モデル 構成，計算の実行など多大の助力をいただいた大林組園 淳生氏ならびに国鉄 藤岡繁樹氏に感謝の意を表します。

\section{参 考文 献}

1）建設省河川局：広域利水調查第二次報告書, 昭 48.8 .

2) Forrester, J.W. 著, 小玉陽一訳：ワールド・ダイナミッ クス, 日本経営出版会, 1972 .

3）小玉陽一・内海武士・合田周平ら：システム・ダイナミッ クス, 共立出版, pp. $200 \sim 323$, 昭 48.6.

4）高棹环馬・池淵周一・園 淳生 : 水の需給構造とその変 化過程に関する研究, 土木学会第 29 回年講, II-83, 昭 49.10.

5）高棹琢馬・池淵周一・藤岡繁樹 : 近畿圈の水需給構造と その変化過程に関する研究, 土木学会第 30 回年講, II109, 昭 50.10.

6) Okada, N. and K. Yoshikawa : System Dynamics Approach to the Water Resource Management Related to the Regional Development, Pacific Regional Conference, 1975.

7）渡辺一司・坂倉省吾：インダストリアル・ダイナミック ス, 東洋経済新報社, 昭 40.3 .

8）前出 3), pp. 697 699.

9）近畿地建企画課 および建設技術研究所：水利用システム に関する調查業務報告書, pp. 50 61, 昭 49.3.

10）前出 9), pp. 32 49

11) 前出 1), pp. $78 \sim 80$.

12）近畿地建：淀川流域の都市開発と河川污濁，昭 46.3 .

13）近畿地建大和川工事事務所：大和川流域環境容量からみ た土地利用計画報告書, 昭 49.3 . その他資料として

14）日本統計年鑑：総理府統計局編, 日本統計協会, 毎日新 聞社.

15）民力：朝日新聞社編.

16）工業統計表，用地・用水編：昭和 40 年度版 46 年度版.

17）公共下水道統計，昭和 40 年度 46 年度版.

(1976.5.24 - 受付) 